\title{
LA AUTOFICCIÓN CÓMICA EN PACO ROCA: EL HUMOR COMO PUNTO DE FUGA AL MODELO TRAUMÁTICO DE NOVELA GRÁFICA
}

\author{
José Manuel Trabado Cabado
}

Universidad de León

Bajo el término de novela gráfica se camufla un amplio espectro de prácticas dispares que tienen, quizá, algo en común: una mayor extensión en sus historias, hecho que derivaba de la emancipación del cómic con respecto a las restricciones que imponían los formatos de publicación. El creador narra su historia y el soporte formal se adapta a lo que se quiere contar. Lo habitual en el cómic, hasta entonces, era lo contrario: las historias se amoldaban a las exigencias de los formatos ${ }^{1}$. Esta mayor extensión permitió roturar nuevos territorios temáticos como bien demuestra el ya canónico ejemplo de Maus de Spiegelman. En esta obra el autor narraba la experiencia traumática de los campos de concentración. Lo hacía, sin embargo, en un discurso de segundo grado: Spiegelman no había vivido esa experiencia sino que era testigo del relato de su padre. Esa complejidad narrativa permitía aunar esa esencia de lo traumático con la narración de lo cotidiano que reflejaba los pormenores de una relación no exenta de tensiones entre padre e hijo. Spiegelman se había nutrido del cómic underground norteamericano pero su encuentro con el genocidio judío dotaba a su obra de una enorme transcendencia. Por otro lado, en Francia un colectivo

\footnotetext{
${ }^{1}$ Para una visión panorámica sobre la relación del concepto de novela gráfica con los formatos de publicación remito a Trabado (2013). La importancia de los formatos de publicación en la poética del cómic es algo convenientemente analizado por Lefèvre (2013). Sobre la novela gráfica cabe destacar el reciente acercamiento realizado por Jan Baetens y Hugo Frey (2015) que complementan otros libros como el de Santiago García (2010), Douglas Wolk (2007) o el de Paul Gravett (2005) por poner solo una pequeña muestra orientativa.
} 
como L’Association impulsó en la tradición europea una profunda renovación en su forma de entender el cómic (Dejasse, Habrand y Meesters 2011). La autobiografía asociada también a una experiencia traumática explicaba en parte obras como La ascensión del gran mal de David B. o incluso la archiconocida Persépolis de Marjane Satrapi. Lewis Trondheim con Mis Circunstancias ensayaba por su parte un modelo de narración autobiográfica y autocaricatura en la que el humor cumplía una función importante. El peso de lo traumático se deslizaba hacia una autocontemplación poco condescendiente que consigue, no obstante, captar la benevolencia del lector. Otras tradiciones como la japonesa ensayaban por su parte una evolución hacia lo cotidiano y lo autobiográfico tal como muestra la obra de Jiro Taniguchi y la denominada nouvelle manga.

Visto así, las tres grandes tradiciones del cómic promueven una profunda renovación en la que la aventura cede paso a la narración del día a día y los géneros tipificados se disuelven bajo las necesidades expresivas de lo autobiográfico. La novela gráfica propició una apertura temática en la que la incidencia de lo cotidiano tuvo un gran peso (Schneider 2010). Dejaba así el cómic de ser un lenguaje aferrado a unas matrices temático-genéricas bastante férreas para convertirse en una herramienta expresiva más que había adquirido suficiente versatilidad como para tratar cualquier tipo de tema. Buscó, así, nuevos ritmos narrativos en los que era posible encontrarse páginas enteras en las que apenas podía entreverse un atisbo de acción. Por otro lado, muchos de estos textos que pasan a formar parte del canon de la novela gráfica poseen, además, una profunda raigambre en el sentimiento de catarsis. El personaje protagonista, anclado en los ritmos de la vida diaria, narra algo de enorme transcendencia emocional. Desde Spiegelman (Chute 2006) hasta Satrapi (Gilmore 2011) los autores de cómic han buscado expulsar sus demonios personales contando lo que son y lo que han vivido ante los ojos del lector. Bajo esa perspectiva parece que este nuevo tipo de relato ha desalojado algo que parecía venir inscrito en lo más íntimo de la genética del cómic: el humor.

En el momento en el que los relatos del cómic amplían su extensión y se emancipan de la prensa como soporte de publicación ensayan una trayectoria que los alejaba del gag que, estructuralmente, exigía una gran condensación y brevedad (Vigara Tauste 1994: 40). A pesar de lo evidente de este tipo de planteamientos, es posible entrever un sólido diálogo en algunos autores cuya obra se sitúa en el centro de esa renovación del cómic con los resortes más genuinos de la narración gráfica humorística. Un caso destacable sería el protagonizado en el cómic francés por Lewis Trondheim. Su obra, ya citada anteriormente, Mis circunstancias, considerada uno de los libros fundacionales de la autobiografía en el cómic francés (Dejasse 2011)², supone un profundo autoanálisis que se inscribe de lleno dentro del auge autobiográfico en el cómic contemporáneo. No se trata, sin embargo, de un relato que insista en la veta emocional e introspectiva tan característica de buena parte de las obras cumbre del cómic actual, sino que

\footnotetext{
2 Para un análisis panorámico, y a la vez profundo de la obra de Trondheim, en el que se destaca su vertiente humorística desde sus inicios remito al trabajo de Bart Beaty (2007: 205-240). Véanse también sus páginas dedicadas a la autobiografía en la tradición francesa del cómic (2013).
} 
ensaya un camino bien diferente en el que tiene lugar una suerte de distanciamiento para consigo mismo que se manifiesta a través de cierta violencia verbal contra sí mismo- llegando incluso a llamarse a sí mismo facha [Fig. 1]- o cuando se desdobla gráficamente en varios personajes con los que establece una relación conflictiva [Fig. 2].
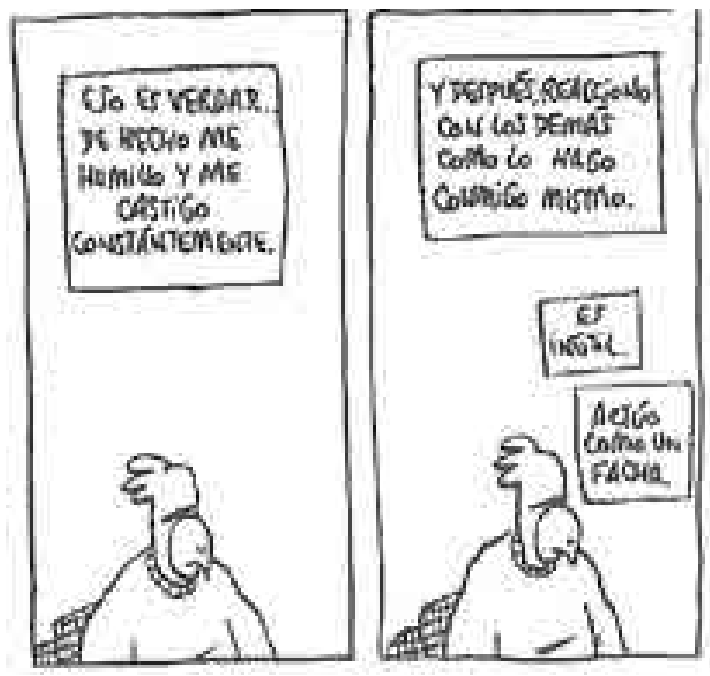

Fig.1. Detalle de la página 18 de Lewis Trondheim, Mis Circunstancias
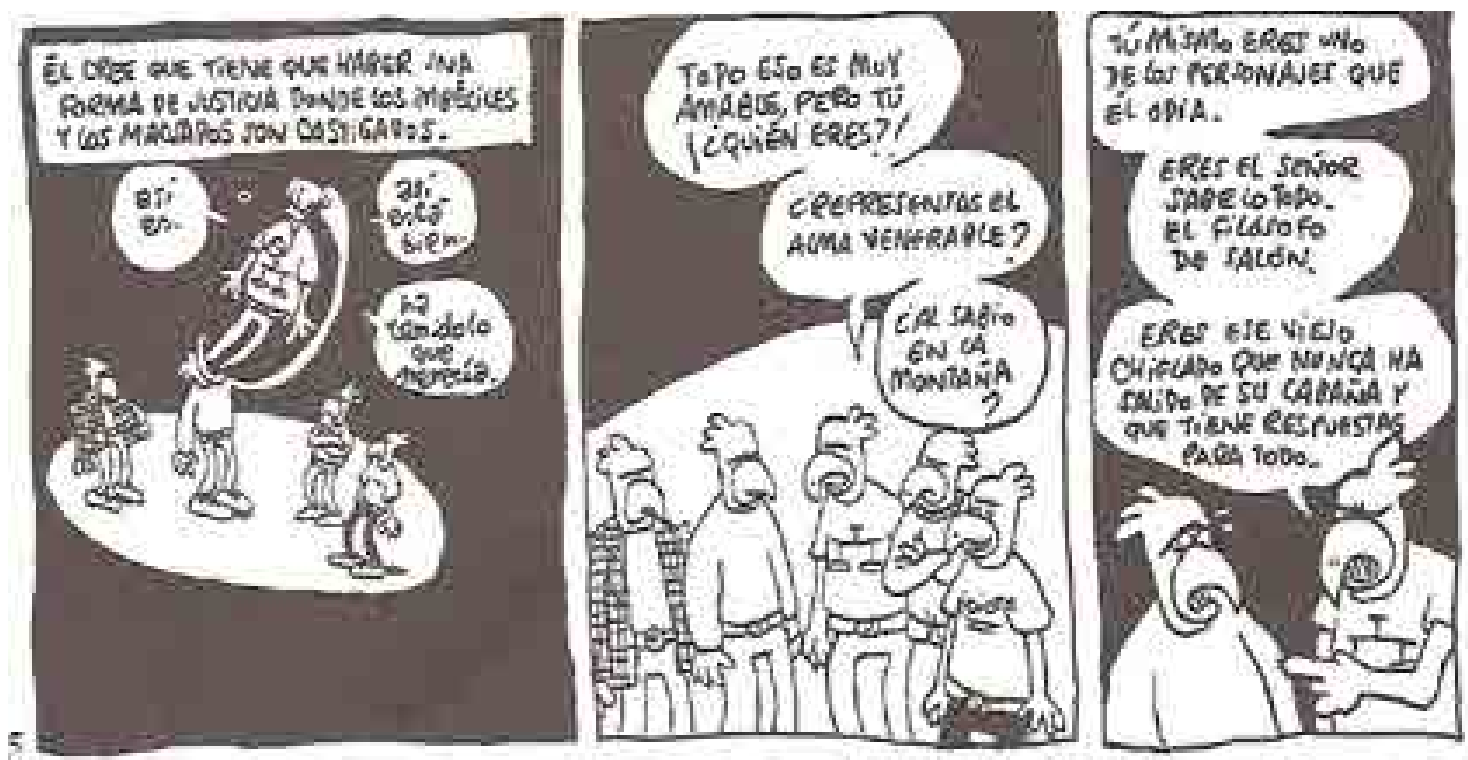

Fig. 2. Detalle de la página 85 de Lewis Trondheim, Mis Circunstancias 
La inserción de lleno dentro del discurso humorístico que propone Trondheim conlleva necesariamente una serie de repercusiones. En primer lugar se adecua a una brevedad exigida por la necesidad de provocar la risa. En el caso de Trondheim sus narraciones se contraen a una página que se agrupan bajo el genérico nombre de Les Petits Riens que va publicando a diario en su blog desde 2006 y que, más tarde, ven la luz en forma de libro gracias a la Editorial Delcourt ${ }^{3}$. Cada página parte de una situación cotidiana en la que el autor es a la vez un punto de vista sobre las cosas que pasan y, también, el protagonista. Existe, además, ese desdoblamiento propio del cómic que adquiere tintes autobiográficos: no solo es una historia sobre uno mismo sino también un autorretrato (Trabado 2012). Si ese distanciamiento consigo mismo se hace explícito construyendo un personaje deliberadamente deformado en el que se exagera una característica de su personalidad -su malhumor en este caso-, también tiene repercusiones en el apartado gráfico al autorrepresentarse como un pájaro antropomórfico ${ }^{4}$. El propio autor explica el mecanismo de ese autorretrato cuando es invitado a hablar en una obra ajena, la publicada por Étienne Davodeau con el título de Los ignorantes. En ella el autor y su amigo Richard Leroy hablan de vino y de cómics. Al preguntarle Leroy por qué Trondheim se dibuja de esa manera, Davodeau ofrece al propio Trondheim la oportunidad de contestar [Fig. 3]. Es una forma de singularizarse y además es un procedimiento rápido de representación. Esa autocaricatura responde a principios psicológicos que buscan la identidad y que se canalizan a través de una estética muy determinada: la rapidez de la caricatura frente a la morosidad exigida por un posible autorretrato.

Así pues, la condensación narrativa, la deformación exagerada de la personalidad y la representación gráfica a modo de animal crean los cimientos necesarios para aunar el recinto de lo privado, signo distintivo de la renovación del cómic, con uno de los rasgos tradicionales de la narración gráfica: el humor. No resulta un caso aislado esta relación de la autobiografía con el humor en el seno del cómic francés. Valdría de ejemplo una obra como la de Manu Larcenet y su Le Combat ordinaire, traducida como Los combates cotidianos, publicada en cuatro tomos entre 2003 y 2008 por la editorial Dargaud, en la que aparecen entremezcladas situaciones cómicas con otras cargadas de una alta intensidad emocional $^{5}$ : el suicidio del padre del protagonista, los vaivenes sentimentales

\footnotetext{
${ }^{3}$ Hasta el momento se han publicado La Malédiction du parapluie, 2006; Syndrome du prisonnier, 2007; Le Bonheur inquiet, 2008 ; Mon ombre au loin, 2009; Le Robinet musical, 2011; Deux ou trois mois d'éternité, 2013. En español la editorial Sinsentido ha traducido La Maldición del paraguas, 2007; El Síndrome del prisionero, 2008 y La Felicidad inquieta, 2010.

${ }^{4}$ La autorrepresentación gráfica en el cómic es algo de enorme complejidad. Es habitual, ya desde Art Spiegelman y su archiconocido Maus hasta autores como David B. en su Ascensión del Gran Mal. Para una visión sobre Maus remito al propio autor (Spiegelman 2011: 110-163).

${ }^{5}$ Para un estudio de la obra de Manu Larcenet y su relación con la autobiografía, más en concreto con la autoficción, remito al artículo de Justine Simon (2008): "Ce nouveau genre d'écriture mélangeant comique et réalisme enrichit de plus la dimension autofictionnelle de l'œuvre car il permet à l'auteur de parler de sujets parfois délicats en les dédramatisant. La force du réalisme des évènements narratifs est mise en abyme grâce à l'humour. Nous réfléchirons en quoi l'humour participe à la dimension vraisemblable du récit". Para un estudio sobre la autoficción remito al volumen de artículos compilados por Ana Casas (2012). A pesar de la extensa, e interesante,
} 

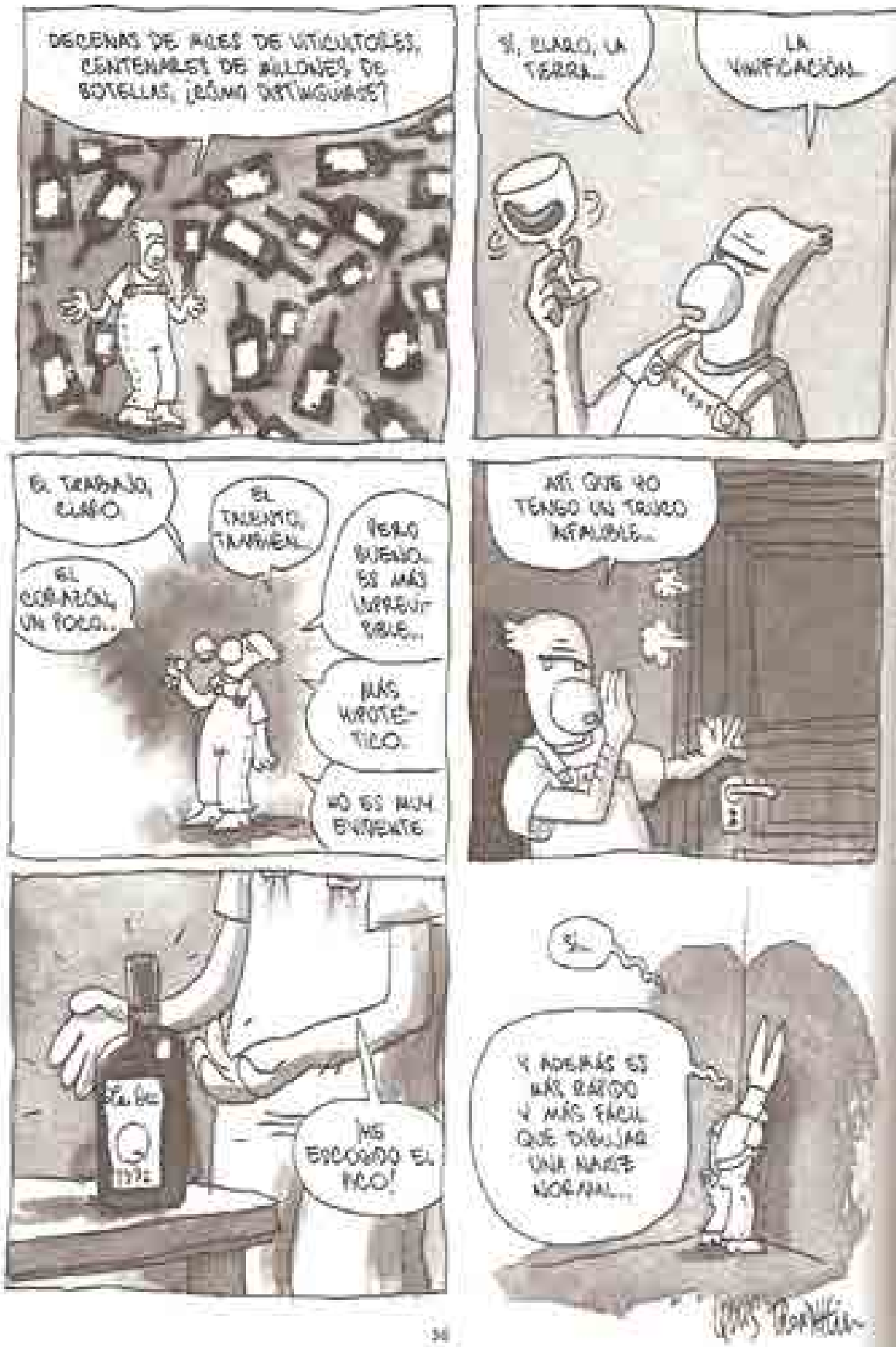

Fig. 3. Página 58 de Los ignorantes, de Etienne Davodeau 
con su pareja, la relación con su hermano, la soledad de su madre, el cierre de los astilleros de su pueblo natal, etc. El espectro temático se amplía dentro de lo que podría ser considerado como novela gráfica y la reproducción de las situaciones humorísticas actúa como un elemento que aporta una mayor dosis de verosimilitud, al tiempo que sirve como contrapeso a un dolor que cristalizaba en los ritmos de lo rutinario. Así en una obra como la de Larcenet se observan registros bien diferenciados que tienen incluso su repercusión en el apartado gráfico. En determinadas páginas se ofrece una voz en off acompañada de un dibujo de corte mucho más realista para concretar plásticamente reflexiones de gran calado que tienen que ver con esa veta traumática. En ellas se narran elementos como los ataques de angustia del protagonista [Fig. 4] que contrastan con el resto de la narración con una paleta cromática muy diferente: un mayor espectro, colores planos y un estilo más esquemático y caricaturesco entroncado con la técnica del cartoon. Allí pueden verse intercaladas bromas como las que el protagonista intercambia frecuentemente con su hermano en un juego de complicidades consistente en coger por sorpresa al otro y gritarle a la espalda que es la policía
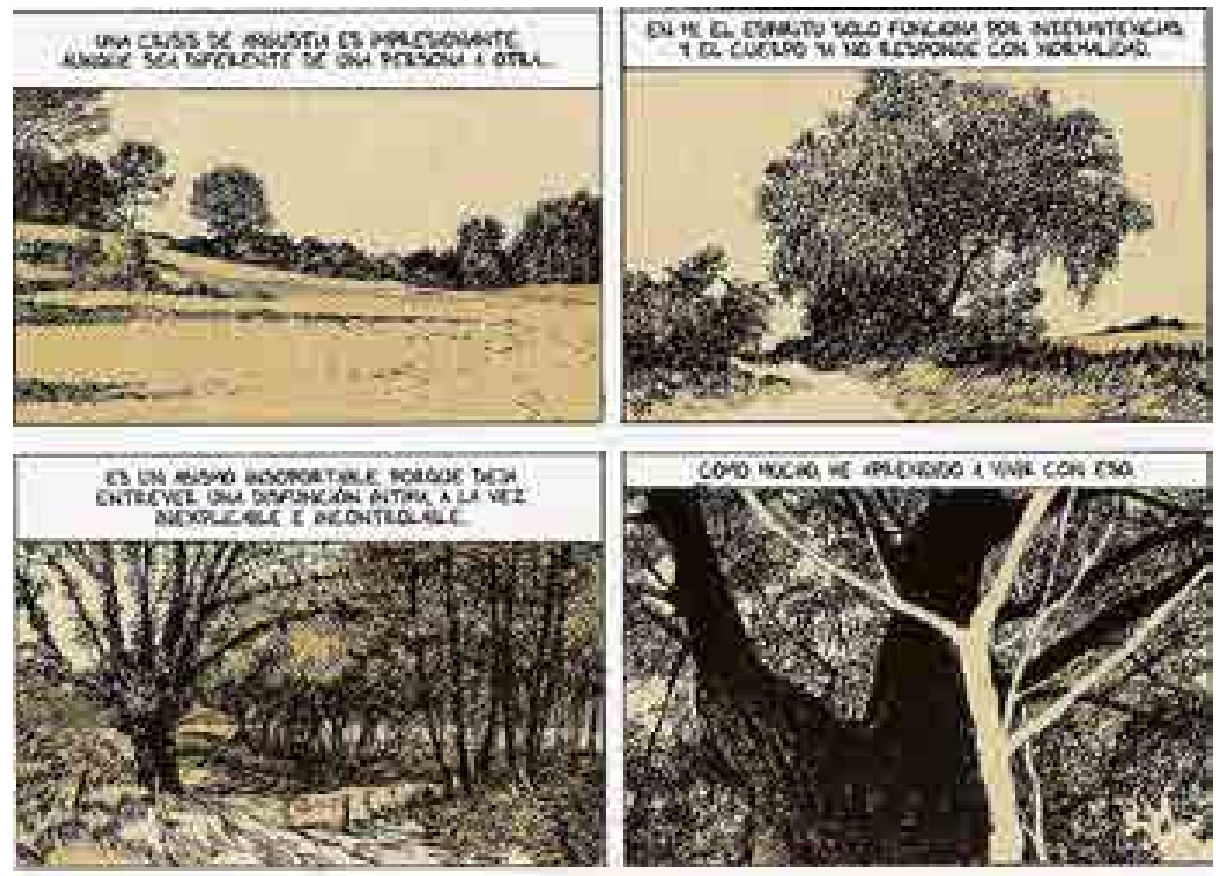

Fig. 4. Detalle de la página 30 Los combates cotidianos, de Manu Larcenet

bibliografía que examina el problema de la autobiografía dentro del cómic apenas se alude al concepto de autoficción. Remito a trabajos recientes como los de Elisabeth El Refaie (2012) o la compilación de Jane Tolmie (2013) que deben ser completados con el volumen compilado por Michael A. Chaney (2011) y el libro dedicado a la autobiografía femenina en el cómic de Hillary Chute (2010). Evidentemente, existen excepciones como la de Jan Baetens (2011) en su análisis de la obra de Dominique Goblet o los diversos análisis sobre la escritura de Lynda Barry y su término autobiofictionalography (Chute 2011).

300 Pasavento. Revista de Estudios Hispánicos, vol. III, n. ${ }^{\circ} 2$ (verano 2015), pp. 295-323, ISSN: 2255-4505 
y pedirle la documentación; lo que causa un susto en el interlocutor [Fig. 5]. Elementos formales como la rotulación o las líneas cinéticas están mostrando que estamos ante otro régimen en el funcionamiento del relato. En ese sentido parece ofrecer otra alternativa al modelo más restrictivo y enfocado en lo traumático de obras como Maus de Spiegelman o Fun Home de Bechdel. Podría hablarse, entonces, de lo "humorístico integrado" para obras como esta de Manu Larcenet o como, pongo por caso, Modotti de Ángel de la Calle, que no está exenta de episodios hilarantes sabiamente mezclados con la narración principal que traza la línea de investigación que sigue el autor, en pos de la reconstrucción de la vida de la fotógrafa y activista política Tina Modotti ${ }^{6}$.
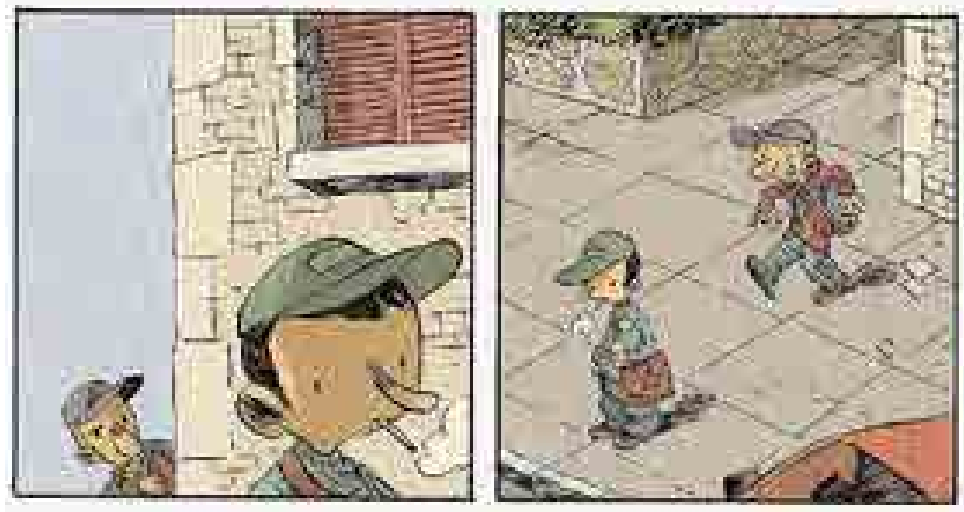

ias

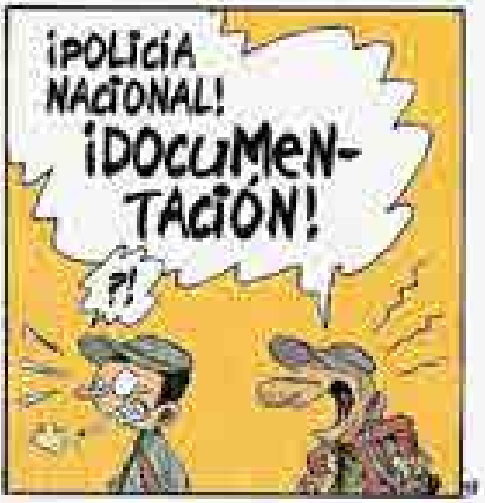

Fig. 5. Detalle de la página 99 Los combates cotidianos, de Manu Larcenet

Por otro lado, Guillaume Bouzard en su Moi, auteur de BD o Jean Philippe Peyraud en su Mine de Rien, o incluso Satrapi en sus Bordados, pueden situarse en esta línea pero con un uso del humor quizá un tanto diferente. No se trata tanto de integrar episodios humorísticos en una narración más extensa sino concebir el humor como algo estructurante que exige una necesaria brevedad. Cristaliza en el modelo textual del chiste y aparece ligado íntimamente a lo autobiográfico. El humor deja de ser un ingrediente más para pasar a ser el núcleo constructivo de cada texto y una filosofía que aúna los diferentes episodios compilados.

No extraña, pues, que la reflexión sobre la identidad y forma de autorrepresentarse sea algo sobre lo que no pocos autores de cómic acaben por reflexionar. Podría valer el ejemplo del propio Paco Roca en la historia "La voz del autor" publicada, originariamente, el 20 de julio de 2014. Como siempre Roca

\footnotetext{
${ }^{6}$ Lo interesante está en el hecho de que la localización de los elementos humorísticos dentro de Modotti surgen asociados a los diálogos y andanzas que el propio autor comparte con Paco Ignacio Taibo. Son episodios que no afectan al relato de la vida de Tina Modotti sino al proceso de construcción y averiguación de ese relato llevado a cabo por Ángel de la Calle. Esta obra tiene, en este sentido, una serie de parentescos muy estrechos con lo narrado en el volumen Diarios del festival del propio Ángel de la Calle, que se sitúa muy en la línea de la práctica editorial de L'Association y su colección Côtelette.
} 
inicia la página con una reflexión general en la que habla de la ambigüedad que suscita cualquier cómic en el que el autor se convierte en personaje. Llega a decir "El autor crea al personaje, pero el personaje altera al creador, hasta fundirse ambos en una extraña simbiosis" (Roca 2014: 54). El diálogo con su pareja en el que le cuenta cómo debe ir a comprarse un pijama para hacer la entrevista es muy ilustrativo. Todo el mundo comienza a confundir al autor real, de carne y hueso, con su personaje, depositario parcial de sus vivencias. A la par, los lectores comienzan a establecer como algo equivalente la voz del narrador

La wo stel autor
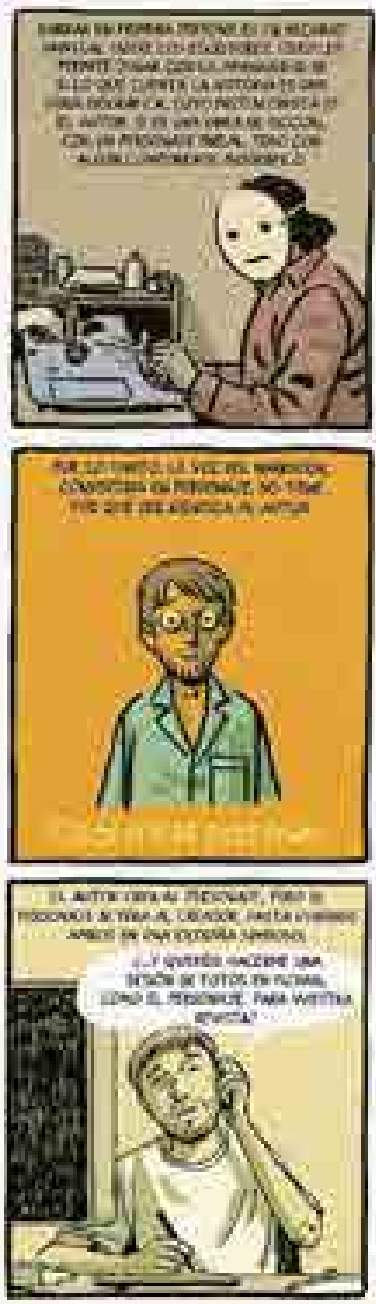
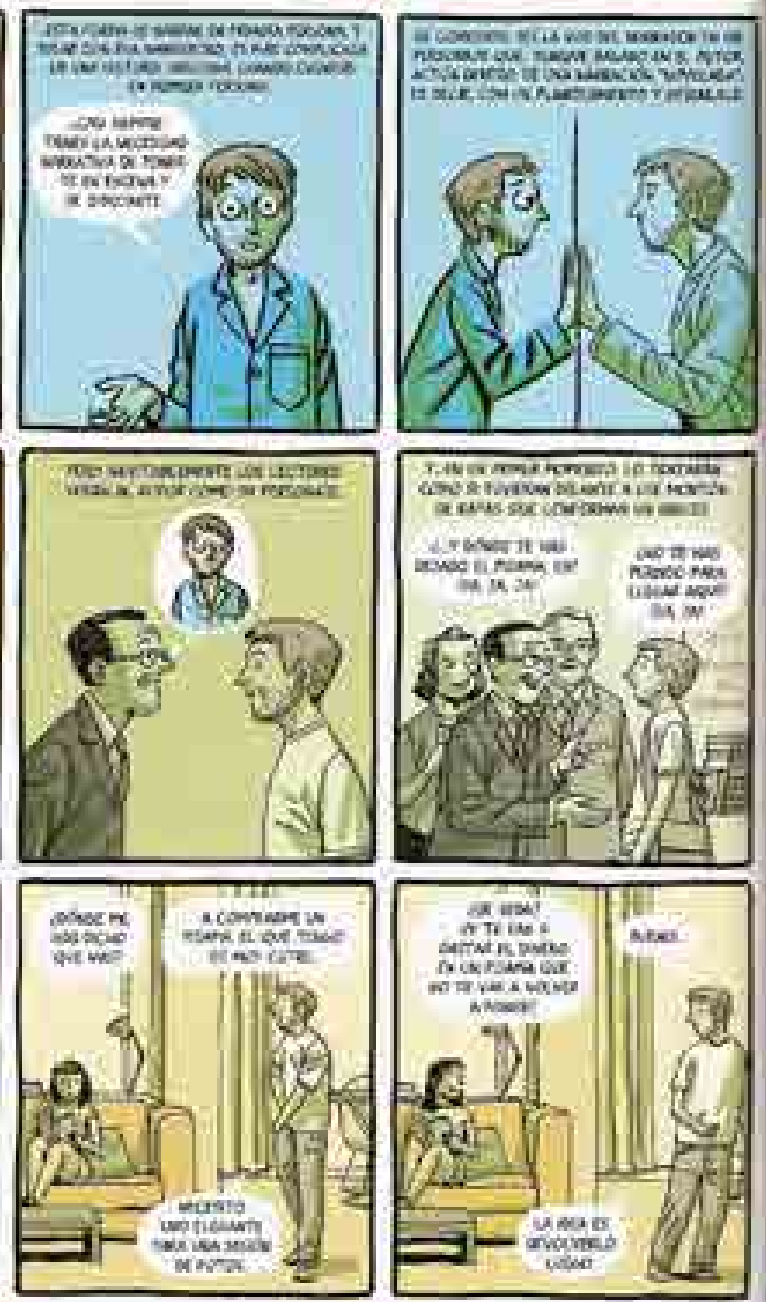

Fig. 6. Página 54 de Andanzas de un hombre en pijama perteneciente a la historia "La voz del autor", de Paco Roca

302 Pasavento. Revista de Estudios Hispánicos, vol. III, n. ${ }^{2} 2$ (verano 2015), pp. 295-323, ISSN: 2255-4505 
con el pensamiento real del autor que lo crea. Es muy significativo que aluda a la imagen de Magritte y su "Ceci n'est pas un pipe" en la viñeta en que aparece su trasunto gráfico con una leyenda que dice: "Ceci n'est pas moi". Evidentemente, es solo una representación gráfica, un signo pero no la realidad aunque, como todo signo, acabe a veces por confundirse con su referente. [Fig. 6]. Como es costumbre, acompañando a esta sólida reflexión teórica sobre el discurso autobiográfico en las viñetas y su relación con la autoficción, existe una deflación humorística. Cuando Paco Roca personaje se dispone a devolver en la tienda el pijama, tras haber realizado la entrevista, es reconocido por el personal, lo que impide la ejecución de sus planes. La última viñeta nos dará pistas sobre la opción tomada: lo habrá cambiado por una talla menor para regalárselo a su chica.

De igual modo cabe entender la página de enorme interés que publicó Miguel Gallardo en el suplemento de El País, Babelia, en la que se hablaba de la autoficción. La página en cuestión se titula "Autor al desnudo" y se publicó el 13 de septiembre de 2008. Interesa no solo por la distancia irónica que toma consigo mismo sino por la representación fluctuante de sí mismo al dibujarse de diversos modos y, finalmente, al acudir a un amigo para que le cuente anécdotas que pueda utilizar y, supuestamente, tras apropiárselas fundirlas con su trasunto gráfico [Fig. 7].

Volviendo al caso de Trondheim, hay que notar que antes de sus Petits Riens, más en concreto en el 2002, había iniciado ya sus Carnets de Bord en los que aprovechaba la coartada que le ofrecían sus viajes para dejar entrar el caudal de lo cotidiano dentro de su obra. La narración del torrente vital del día a día permitía diluir la trabazón narrativa y ocasionaba que algunas escenas cobrasen protagonismo e insinuasen un posible funcionamiento como unidades autónomas (Trabado 2014) ${ }^{7}$. Bajo esa fragmentación contextual podían encararse las diversas situaciones bajo el prisma de lo humorístico. Efectivamente, allí se anticipaba en cierto modo la aparición de sus Petits riens.

La inserción del autor como protagonista de su propio discurso impide que éste tome un camino efectivo hacia la sátira hiriente. Así, la autobiografía se convierte en un mecanismo de conexión con el cómic más vanguardista y contemporáneo pero también como una estrategia para atemperar el daño de un posible registro satírico. Se solicita en cierto modo una empatía que acabe por dinamitar las barreras de protección ante un discurso crítico.

En este sentido cabría la posibilidad de realizar una comparación de lo apuntado para Trondheim y otros autores con la obra de Paco Roca, otro de los baluartes de la novela gráfica española. Sus pequeñas narraciones publicadas primero en la prensa -más en concreto en el diario Las Provincias-y, más tarde, en forma de libro configuran las pequeñas andanzas de un autor de cómic que reflexiona sobre la vida que lleva. Lo hace desde un espacio singular: su propia casa y, además, en pijama. Parte así de un elemento íntimo para convertirlo en un discurso público. La transición que permite injertar ese espacio doméstico

\footnotetext{
7 Sobre la importancia de los diarios en forma de cómic remito también a los trabajos de Isaac Cates (2011) y de Juan Manuel Díaz de Guereñu (2014: 103-125).
} 


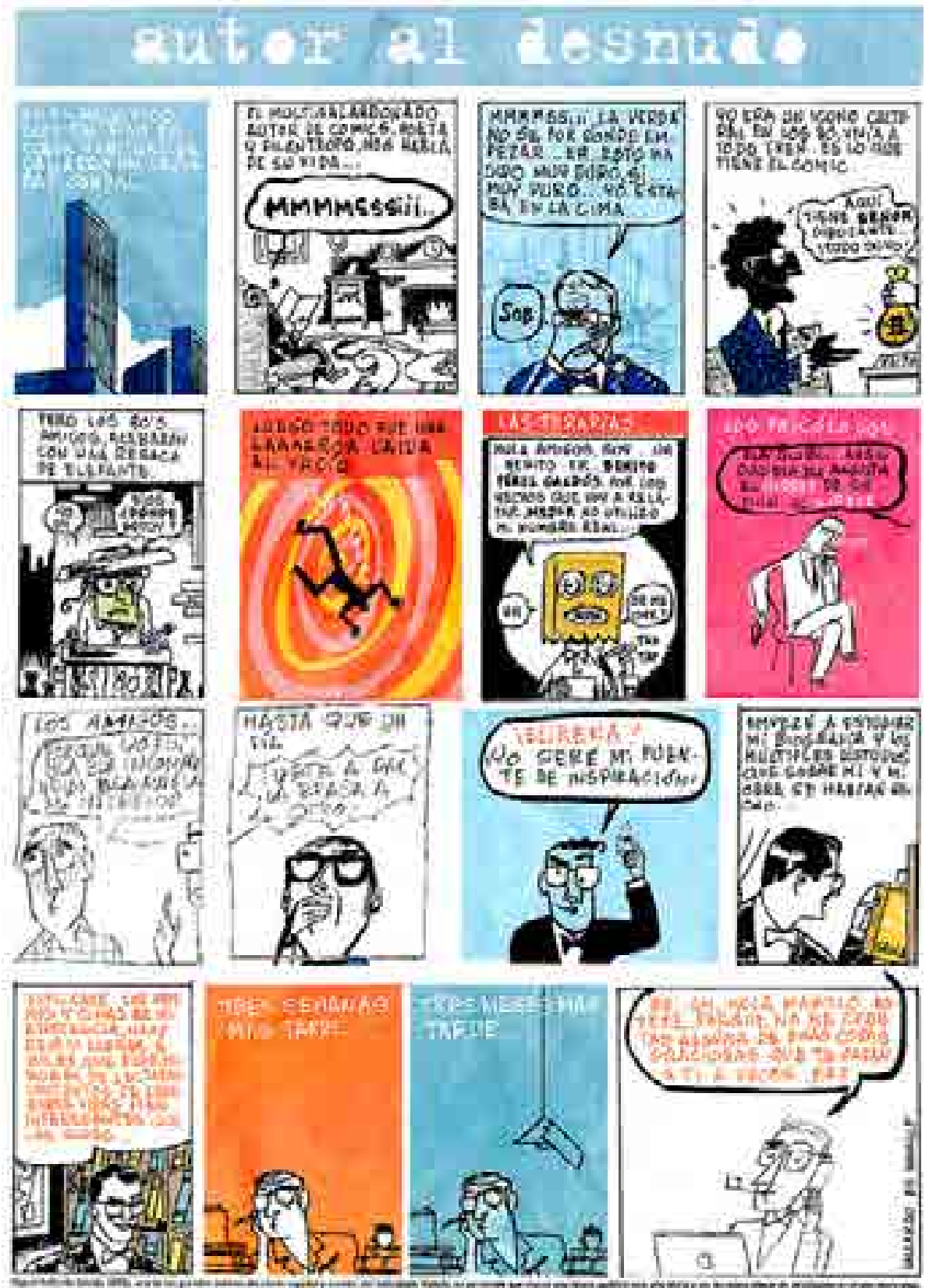

dila

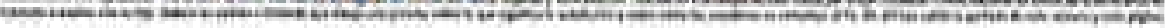

Fig. 7. Página de Miguel Gallardo publicada en el suplemento Babelia el 13 de septiembre de 2008 
en el ámbito de la prensa pasa por contar con el humor como una estrategia legitimadora. Si Trondheim había metamorfoseado su apariencia física en un ave, convirtiéndose así en un personaje, Paco Roca opta por otro signo de extrañamiento: el pijama.

Si examinamos la compilación de historias publicadas bajo el nombre de Memorias de un hombre en pijama podemos establecer una serie de mecanismos compositivos. Uno de ellos a destacar es la importancia del final. Ahí parece centrarse todo el poder humorístico desde el momento en el que el lector parece ser el testigo de una epifanía que experimenta el protagonista. La revelación supone una suerte de aprendizaje tras una experiencia. Podría así constituirse una pequeña filosofía basada en las vivencias cotidianas en las que el propio protagonista queda en entredicho. Se pone a sí mismo como ejemplo del que se puede extraer una conclusión. En esa viñeta final se puede ver en muchas ocasiones al protagonista con los ojos muy abiertos, indicativo de la señal de sorpresa que acaba de experimentar [Fig 8]. No deja de ser un signo gráfico dictado por la necesidad de ser muy expresivo en una historia más breve. Desde ese punto de vista se puede establecer una relación directa entre la extensión de la narración y la retórica corporal dibujada ${ }^{8}$. Además en este sentido puede verse como un signo demarcativo que indica gráficamente dónde se concentra el efecto humorístico. Opera como un indicador de lectura al mismo tiempo que configura un estilo narrativo personal en el texto humorístico relacionable con la forma que posee el autor de enfrentarse con la realidad. Esa forma de dibujarse con los ojos muy abiertos indica la perplejidad ante el mundo que le rodea y esa súbita conciencia de algo que había pasado inadvertido para él.

Otro rasgo pertinente está en la capacidad de exageración que tiene su punto de apoyo en algún elemento tomado de la vida diaria. Esa exageración tiene como misión hacer visible algo que la rutina ha normalizado pero sobre lo que la mirada atenta del artista quiere reflexionar desde una perspectiva lúdica. Así por ejemplo funciona la historia sobre los tuppers. En ella se imagina todo un mundo en el que los tuppers van y vienen de una forma coordinada. Ese flujo de traslado en el que las madres surten de alimento a sus hijos se convierte, a los ojos del autor, en algo universal. Tiene mucho de verdad ya que en gran parte la obra humorística de Roca podría definirse como un humor contextualizado en el que el relato toma sus anécdotas de problemas compartidos por una generación determinada. El humor nace de esa observación de lo cotidiano pero tamizado por la pertenencia a una situación contextual muy determinada: la posición del artista como miembro de una comunidad más amplia de la que puede erigirse como ejemplo paradigmático. No solo es una serie de variaciones obsesivas que desmenuzan los adentros de un personaje parcialmente identificable con el autor, tal y como sucede en Trondheim. Posee esa reflexión una capacidad sinecdóquica por la cual esa anécdota se hace extensible a los demás integrantes de esa comunidad. Ese humor es una forma de risa colectiva. Nadie se ve

\footnotetext{
${ }^{8}$ Los ojos muy abiertos, en señal de sorpresa, es algo codificado en el marco de los cómics humorísticos (Gasca y Gubern 1994: 127).
} 

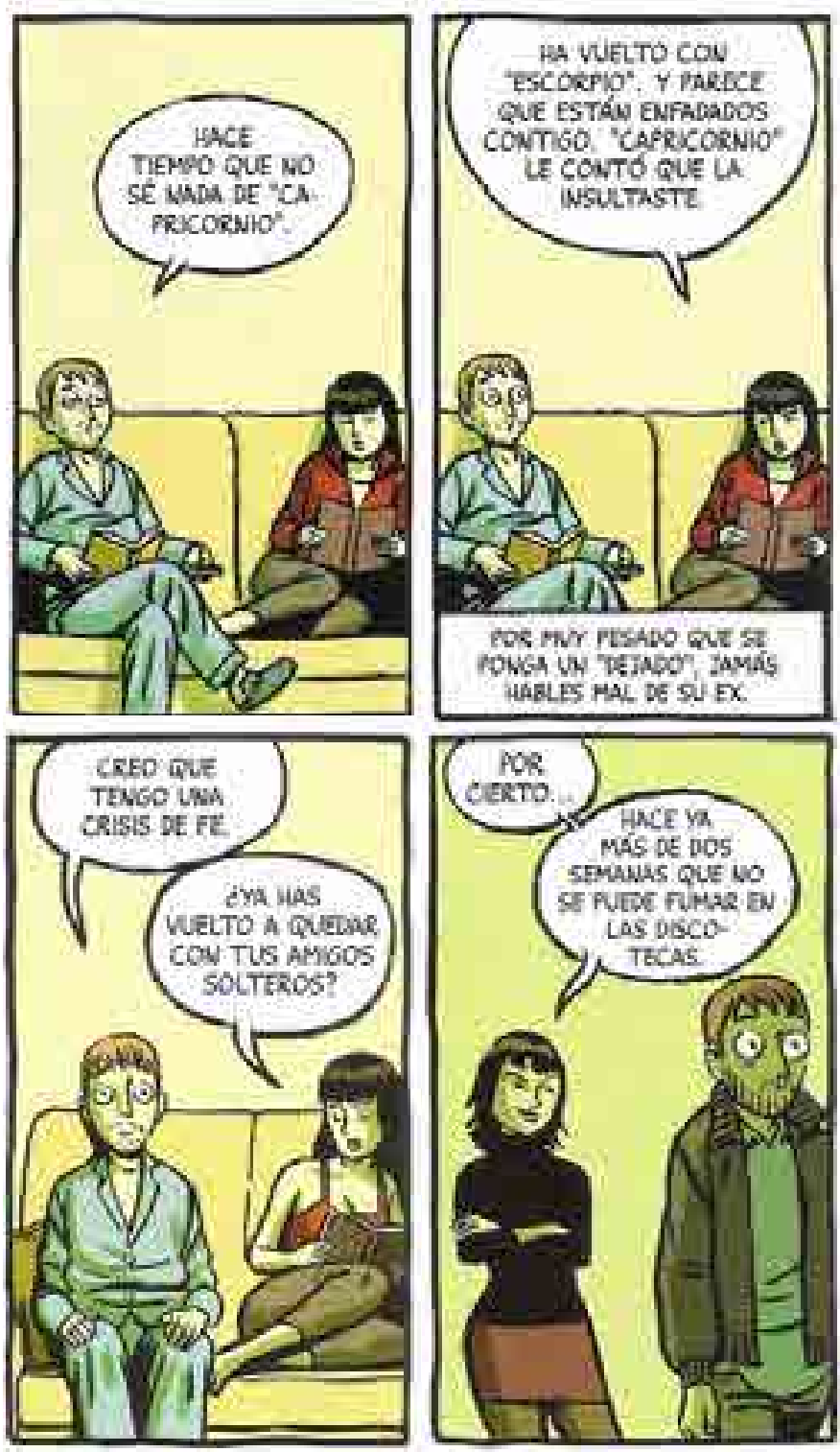

Fig. 8. Detalles de las páginas 23,43 y 81

de Memorias de un hombre en pijama, de Paco Roca

atacado. En este sentido Trondheim plantea una obra que posee una tendencia centrípeta: toda la narración parece pivotar sobre la figura de su autor y su obra, lo que explica las abundantes autorreferencias a su propio trabajo. Ni siquiera este rasgo pasa inadvertido y acaba por burlarse de sí mismo en este aspecto al 
dibujarse como un reo condenado a no poder hablar de sí ni de su obra en una semana [Fig. 9].
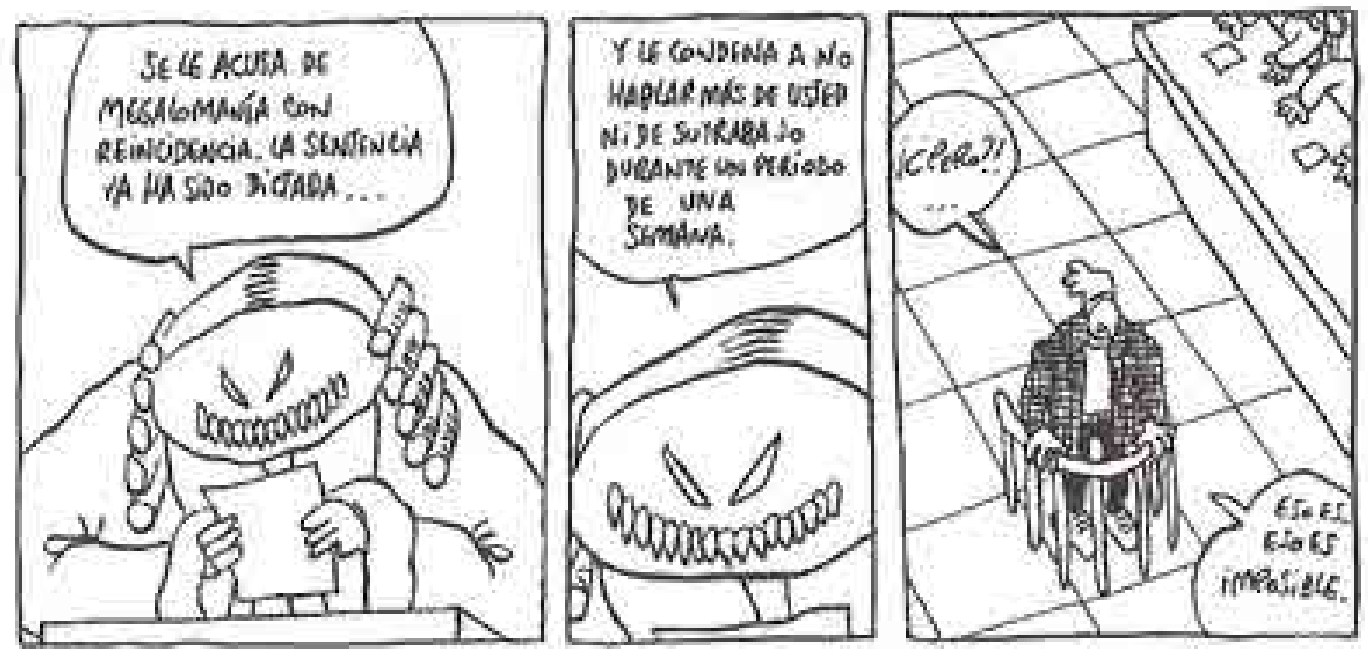

Fig. 9. Detalle de la página 16 de Mis Circunstancias, de Lewis Trondheim

Volviendo al episodio de los tuppers de Paco Roca, en ese viaje universal se instaura además una figura retórica en la que se establece una identidad entre dos elementos muy dispares. Esa disparidad incongruente genera el sentido humorístico. En este caso Roca imagina (y dibuja en esa breve historia) una red de controladores que regulan el tráfico de tuppers como si de un aeropuerto se tratase [Fig. 10]. Esa incongruencia que cristaliza en una metáfora humorística no sólo se queda en un registro puramente lúdico sino que introduce un nuevo conocimiento. La generalización de esa práctica invita a una reflexión sobre el momento en el que se vive. Desde este modo estas pequeñas historias podrían ser leídas como si se tratase de una serie de microensayos sociológicos sobre lo cotidiano que el humor vuelve digeribles para el gran público. No solo se inicia esa reflexión que puede ser apoyada desde un punto de vista colectivo sino que en la parte final el autor introduce una observación muy personal que denota una vena ingeniosa. El autor parte de un conocimiento ampliamente compartido para, sobre esa práctica, extraer una conclusión muy singular: "Los tuppers han servido a las madres para ver más a menudo a sus hijos". Esa reflexión general se apoya en el caso concreto encarnado por Paco Roca. Parte de su experiencia personal para trascenderla y convertirla en un relato generacional. Sin embargo, la vertiente puramente individual del discurso sigue presente y está patente en esos chispazos de ingenio que se aglutinan en la parte final que resuelve la lógica del relato. La metáfora presenta una falsilla sobre la que releer la realidad. Examinar ese tráfico de tuppers como una estrategia de la que se valen las ma- 

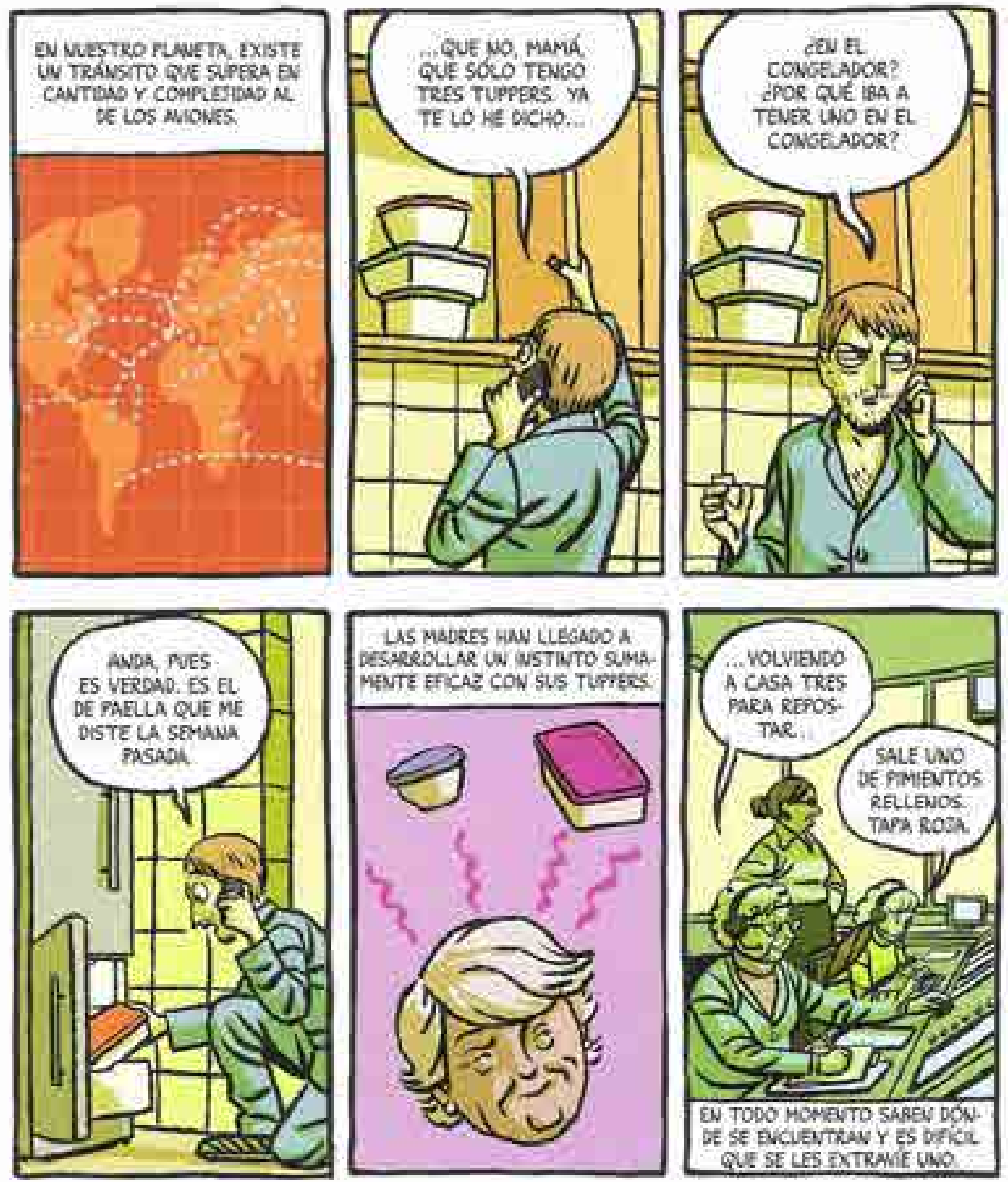

Fig. 10. Página 70 de Memorias de un hombre en pijama, de Paco Roca

dres para poder ver a sus hijos con cierta asiduidad presenta una visión insólita de algo rutinario. Ese aporte carga de nueva información lo ya consabido, lo revitaliza y, en cierto modo, lo festeja. 
No es un caso aislado este uso metafórico con signo humorístico. Es también visible en otros lugares (Roca 2011: 25) cuando el propio autor se autodenomina "hombre veleta": aquel que no tiene una opinión formada sobre algo sino que intenta amoldarse a la visión de su interlocutor, normalmente femenino, con el único fin de agradar [Fig. 11] ${ }^{9}$. En este caso la sutileza compositiva de la página pone en funcionamiento una serie de recursos supeditados a esa intención humorística. Así, por ejemplo, en tres viñetas se muestran tres situaciones diferentes en las que el relato funciona bajo tres regímenes muy dispares. El recuerdo de una conversación con una chica en la que su extremado afán por gustar le hace caer en el ridículo que viene interpretado por la voz del narrador en el cartucho indicando "Mi estilo es no tener estilo". Esta última afirmación sirve como enlace de la siguiente viñeta en la que se cita una de las famosas frases atribuidas a Groucho Marx, que funciona como auctoritas de lo humorístico asociado a una filosofía vital: "Estos son mis principios, señorita, si no le gustan tengo otros". En ese caso se dibuja al actor en blanco y negro. La tercera viñeta, y última de la fila, hace virar al relato hacia otro tipo de representación para rematar esta minisecuencia cómica basada en un juego de palabras: "A falta de mejores armas para ligar y convertirme en un macho alfa... me he convertido en un macho veleta". El autorretrato, ahora, no pretende un afán mimético en el que se pueda reconocer al Paco Roca real en el personaje dibujado sino que es una elaboración simbólica en la que su rostro aparece sustituido por una serie de caras que remedan, efectivamente, una veleta. La remodelación del macho alfa: líder de la manada que fecunda las hembras traspuesta al orbe de las relaciones personales se degrada humorísticamente en una nueva creación léxica basada en el uso popular de otro tropo como es el calificativo de veleta para quien cambia continuamente de opinión y parecer. Parece como si el lenguaje del cómic se adecuara perfectamente a las exigencias del texto humorístico desde el momento en que ambos actúan por elipsis, buscando la síntesis y ofreciendo un giro inesperado.

Los gags humorísticos del hombre en pijama venían a veces prefigurados en obras anteriores. Esa página "del hombre veleta" pudiera situarse en consonancia con lo que ya el propio autor había tratado en otra serie publicada en la revista Humo entre los años 2005 y 2007 titulada Como cagallón por acequia. Allí el protagonista, Ulises, se separa de su pareja y parece inmerso en una crisis existencial que lo lleva a sentirse desnortado. Algo similar había tratado en Las calles de arena pero la gramática constructiva del relato en éste obedecía en gran medida a las maneras de lo fantástico (Trabado 2013). Ambos personajes, Ulises y el anónimo protagonista de Las calles de arena, son seres extraviados en diferentes laberintos: uno físico que emerge en medio de las calles de su propio barrio y que posee una índole misteriosa y otro figurado, más indefinible y conformado por la maraña de sentimientos sin identificar. La referencia del título

\footnotetext{
${ }^{9}$ En otro lugar se vale de la misma imagen y del mismo concepto. En ese caso sirve para iniciar la historia: "Reconozco que siempre me ha costado llevar la contraria en una conversación aunque no esté de acuerdo con la opinión. Como no me gusta discutir, incluso acabo dando la razón. He sido siempre algo así como un hombre-veleta" (Roca 2011:124).
} 

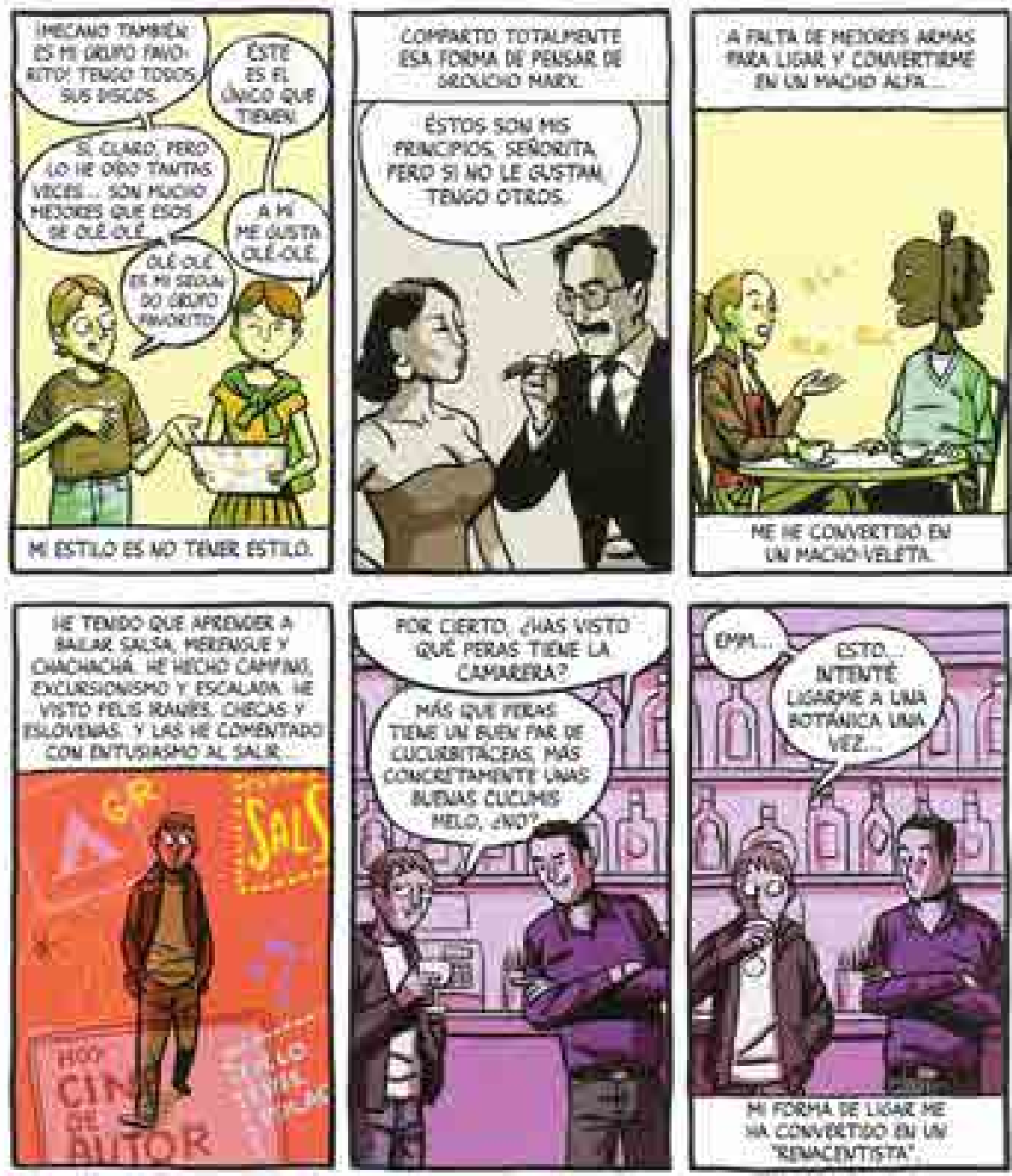

Fig. 11. Página 25 de Memorias de un hombre en pijama, de Paco Roca

- Como cagallón por acequia- indica bien a las claras el espíritu del protagonista que se deja guiar por los acontecimientos. Es, en cierto modo, otro "hombre veleta". Más allá de estos parecidos conceptuales en la construcción del personaje protagonista, en algunos casos pueden verse realizaciones muy próximas que muestran claramente la cercanía de Como cagallón por acequia con las Memorias de un hombre en pijama. Baste un ejemplo como el que rescata la cita de un cuento de Borges por el que el autor parece tener una especial predilección. Se trata, aunque no se diga explícitamente, del cuento titulado "El Otro" incluido en el volumen El libro de arena. En este relato un Borges adulto se encuentra con 
otro Borges mucho más joven. En la serie Como cagallón por acequia, Ulises tras hacer un balance vital de lo que ha sido su vida pregunta a su amigo qué consejos le daría a su "yo" de 14 años. La respuesta de éste propone un cambio de tono en el que se puede apreciar una reconducción de lo fantástico a lo humorístico: "Me diría que si alguna vez dudo en quedar con una tía, primero me haga una paja y luego decida si la llamo o no. Y que no tuviese amigos sin coche a los que tuviese que recoger en hora punta"10. La actitud melancólica e intelectual de Ulises contrasta con el pragmatismo de su amigo que sitúa a su interlocutor con los pies en la tierra. La risa sirve como un antídoto para despejar la esencia de lo amenazante que va implícito en lo fantástico. Al mismo tiempo se aminora la deriva metafísica, y a la vez nostálgica, que pudiera tomar la conversación para virar hacia lo cotidiano. El humor presenta, así, un anticlímax que disuelve la esencia de lo fantástico. Esa forma de proceder emparenta el gag de Como cagallón por acequia con el episodio de Memorias (Roca 2011:107-108) en el que no lo plantea ya como una posibilidad sino que ejecuta esa imaginación sobre el escenario de la página. La conversación entre el Paco Roca adulto y el joven no deja de ser hilarante. Cuando el joven Paco Roca le pregunta sobre lo aprendido a lo largo de todos estos años la respuesta provoca la risa. Los grandes conocimientos adquiridos pasan por negar la eficacia de una cuchara para evitar que una botella de champán pierda el gas, que no es malo tomar una tónica tras un Baileys, que evite la moda de los ochenta, etc. Ante la decepción causada por estas palabras, le pregunta sobre las chicas y la repuesta vuelve a no estar a la altura de las expectativas del joven ansioso por ver cómo será su futuro ${ }^{11}$. Ahí le espeta que para tener 25 años más no parece haber aprendido mucho. El maduro Paco Roca ejecuta su venganza al aconsejarle a su joven "yo" que le diga a su madre que no siga dejando dobladillo en los pantalones. No va a crecer mucho más. En ese jocoso diálogo en el que el protagonista se autoflagela a través de un artificio retórico hurtado al relato fantástico (el Doppelgänger-que aparecía ya en Las Calles de arena-) se puede observar un relato en segundo grado que muestra a un hombre incapaz de alcanzar la madurez; nada ha aprendido y el humor que refleja la escena actúa como herramienta eficaz a la hora de desinflar retóricamente el "yo" del autor. Borges actúa como un señuelo que apunta con encumbrar el discurso pero el traslado de ese fetiche literario a la vida provoca una disparidad tan grande con respecto al modelo que no puede sino provocar la risa. No se trata de socavar una referencia intertextual sino de comprobar cómo el ejemplo elegido -el propio autor- no está a la altura del referente esgrimido al principio con fruición intelectual por el autor. Este desdoblamiento

\footnotetext{
10 Cito por la recopilación que aparece en la obra de Koldo Azpitarte (2009). Sin paginar. El fragmento se encuentra en la página número 4.

${ }^{11}$ Si examinásemos desde un punto de vista pragmático los mecanismos lingüísticos de los que se vale Paco Roca para provocar la risa, se podría observar que en ocasiones como esta se incumplen algunas de las máximas establecidas por Grice para describir el principio de cooperación que regula las conversaciones. En concreto, se trata de la máxima de relación o pertinencia por la que se nos insta a ofrecer una información relevante. No ocurre así en la página de Paco Roca o, al menos, así lo cree el joven "yo" del autor. Para una aplicación de los principios de Grice en el análisis del cómic remito al trabajo de Yus Ramos (1995).
} 
del autor en otro personaje se puede ver en otra página de las Memorias (Roca 2011: 55) en la que un Paco Roca adulto recrimina con un pescozón a su yo joven el hecho de no haber aprendido más idiomas en su juventud. Es una forma de lamentar un tiempo perdido al constatar en el presente su incapacidad para comunicarse en otros idiomas. No es la última vez que Roca trata ese desdoblamiento y narra el encuentro con sus "yoes" de otros tiempos, como puede verse en la historia "La leyes (temporales) del mercado" en la que el Paco Roca actual se encuentra en su casa con su "yo" de los años 80 y con el yo del futuro, del 2030. Hablan de su visión del autor de cómic pero cada uno desde su tiempo; está lleno de reproches y pequeñas puyas de unos para con otros. El yo del futuro regresa para pedirle al yo del presente que le preste la libreta de apuntes porque se ha quedado sin ideas [Fig. 12].
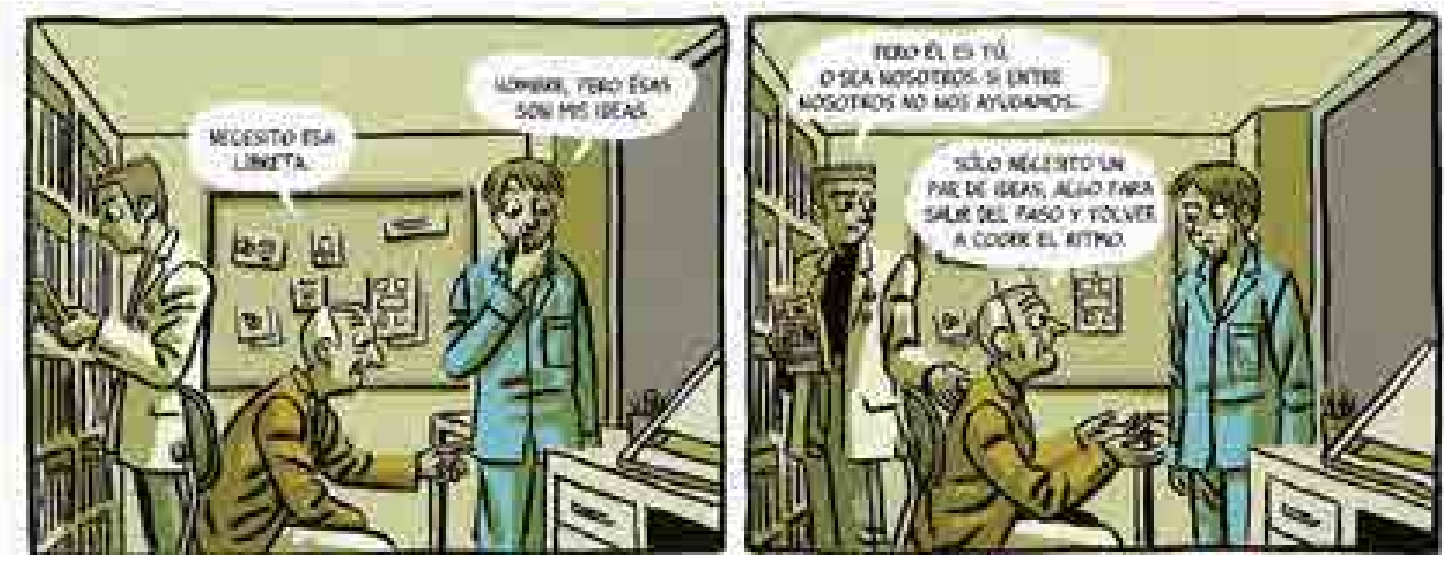

Fig. 12. Detalle de la página 69 de la historia titulada "La leyes (temporales) del mercado" incluida en Andanzas de un hombre en pijama

En la historia titulada "La eterna escritura" publicada el 2 de febrero de 2014 en El País y recopilada más tarde en el volumen Andanzas de un hombre en pijama insiste en ese motivo temático en lo que constituye una estupenda explicación sobre cómo construimos nuestro pasado. Los textos de apoyo exponen cómo nuestra memoria va rehaciendo el pasado para volverlo coherente con lo que somos en el momento actual. Es una reescritura de lo que fuimos. Bajo ese pensamiento de hondo calado, Roca se adentra en sus propios recuerdos y admite que hubiera suprimido ciertos silencios en determinadas ocasiones y que, en otras, habría borrado palabras que dijo y no debía. Desde ese balance emocional se pasa a la parte final en la que la vis comica tomará el mando del discurso. Al proponer eliminar las hombreras que llevaba en los años 80 , surge su "yo" de entonces para recriminarle esa actitud y espetarle si no se ha planteado qué piensan sus "yo" del pasado de lo que es ahora mismo. Paco Roca, personaje, se queda meditabundo y solitario en la última viñeta diciéndose a 
sí mismo que no se recordaba con tan mal humor. La estructura temática de la página arranca desde una idea general, pasa al análisis de su situación personal y deriva, finalmente, en un gag humorístico que recoge esa idea tan recurrente en Roca del Doppelgänger, eso sí, un Doppelgänger humorístico [Fig. 13]. Al igual que en otras ocasiones el discurso fantástico desemboca en un chiste y lo inquietante se diluye en pos de otro tipo de reflexión que no juega con el miedo sino con la risa. Ver al autor rehaciendo un libro que se titulada Su Vida podría haber despertado los resortes de una escritura de lo fantástico; la aparición de su otro "yo" vendría a incidir en esa veta de lo insólito pero la recriminación y la reflexión final desalojan definitivamente, después de haberlo insinuado, cualquier atisbo de una escritura enraizada en lo siniestro.
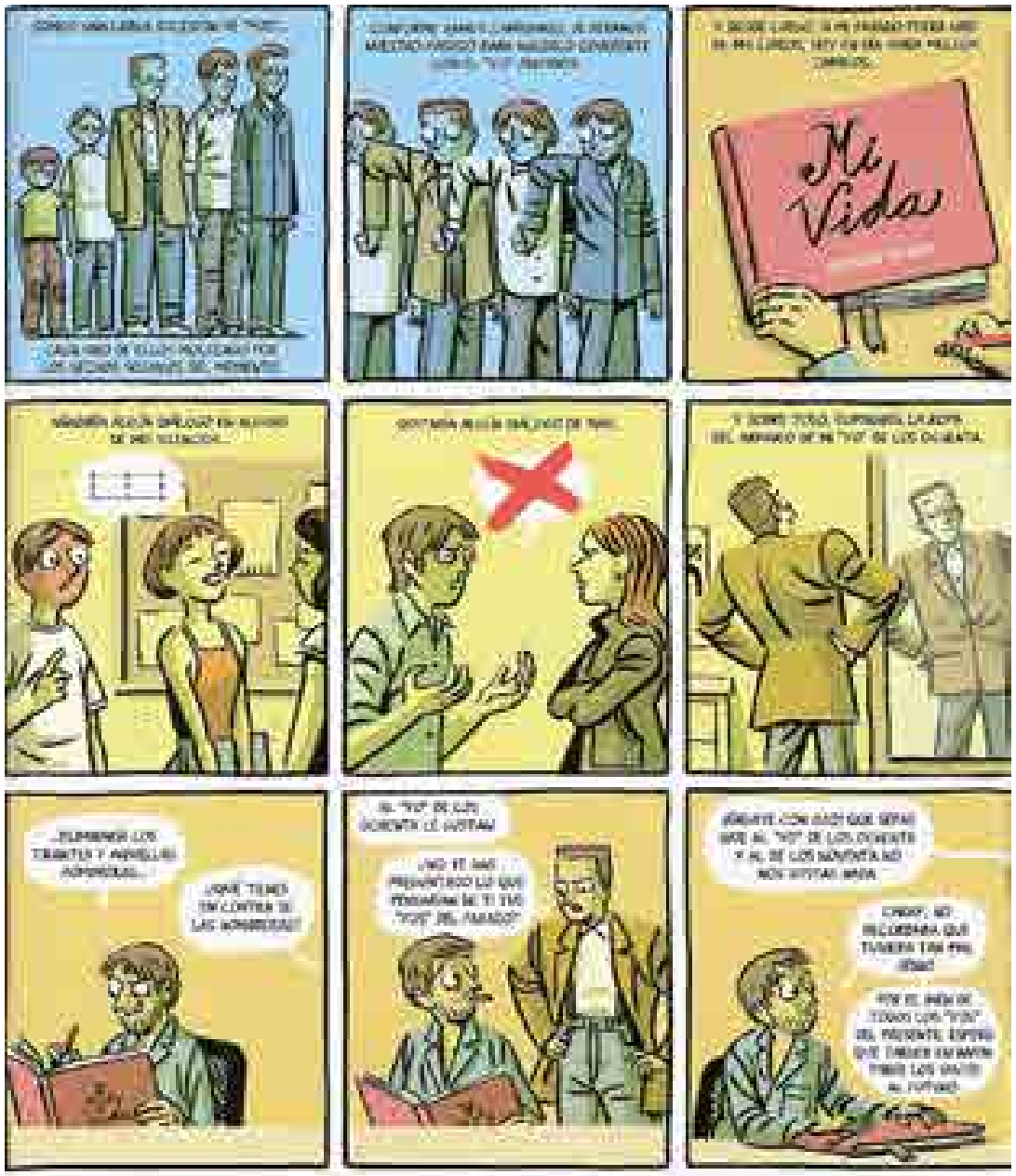

Fig. 13. Página 31 de Andanzas de un hombre en pijama perteneciente a la historia "La eterna escritura" 
En el catálogo de procedimientos compositivos de las páginas humorísticas de Paco Roca esa desfiguración del sujeto protagonista encaja con la interpretación metafórica de las realidades sociales. Un buen ejemplo de ello son las páginas dedicadas a examinar desde la óptica del que no tiene hijos la problemática de los padres. Al autor le gusta imaginar que todos los padres forman parte de una logia secreta en la que se comparten las desventuras de las noches sin sueño. El lenguaje gráfico, basado en la situación cotidiana, muta en estos incisos a un tipo de narración muy diferente en la que se proyectan gráficamente las imaginaciones del autor. En este caso la asociación entre padres y logia secreta se vale del mismo procedimiento que la trasposición de las madres a controladoras aéreas de tuppers. El procedimiento retórico sigue siendo básicamente el mismo. Una vez más lo siniestro es citado como posibilidad pero no asumido como una realidad dentro del relato.

También dentro de los mecanismos que activan el discurso humorístico en las páginas de Paco Roca está la tentativa de incumplir alguna de las normas tomadas como esenciales como, por ejemplo, la planificación por parte del hombre del regalo a su pareja en la fecha de cumpleaños o el peligro de romper la cadena de frío en la manipulación de los alimentos. Ambos episodios son tratados por Roca bajo un procedimiento semejante que se articula gráficamente del mismo modo. La inclusión de una viñeta en la que una autoridad parece dictar esa norma o imponer un castigo por haberla incumplido crea una situación de indefensión cómica en el protagonista. El personaje se ve, así, víctima de una máquina infernal confeccionada por costumbres y usos que intenta seguir pero que, debido a su torpeza, solo a duras penas puede hacerlo. No se trata de una rebelión contra los dogmas establecidos sino de un relato del esfuerzo por seguir todo aquello que parece escrito. Así veremos a un juez acusándolo de no saber escuchar a su pareja cuando insinuaba posibles regalos [Fig. 14] o al mismo Dios dictando a modo de Mandamiento la prohibición de romper la cadena de frío. La inclusión de esas normas o costumbres viene magnificada a modo de hipérbole [Fig. 15] que sitúa al protagonista en una posición de fragilidad.

No es solo un espejo que deforma un posible autorretrato. No actúa en el perímetro de lo individual sino que su experiencia emerge con una vocación claramente social. Existe así un diálogo entre lo individual y lo social que acaso explique también obras como Arrugas o Los surcos del azar.

Se entiende así que el humor no desplace esa visión de una época. No es el fin sino una herramienta para verse a sí mismo y para contar lo que se observa en su entorno. La página dedicada a la evolución de las conversaciones en torno a las comidas es un buen ejemplo. En las doce viñetas que constituyen cada relato se muestran tres temporalidades en las que se analiza la función del lenguaje y del diálogo como acompañante de las comidas. Se ejemplifica con una conversación en la Edad Clásica en la que se habla de mitología; a continuación se yuxtapone otra situada en la Edad Media en la que se debate sobre cuestiones teológicas. Para finalizar, en una tercera temporalidad, la actual, donde vemos al autor con unos amigos debatiendo sobre la composición de un grupo musical. Todo finaliza cuando uno de ellos comprueba en su teléfono la información 

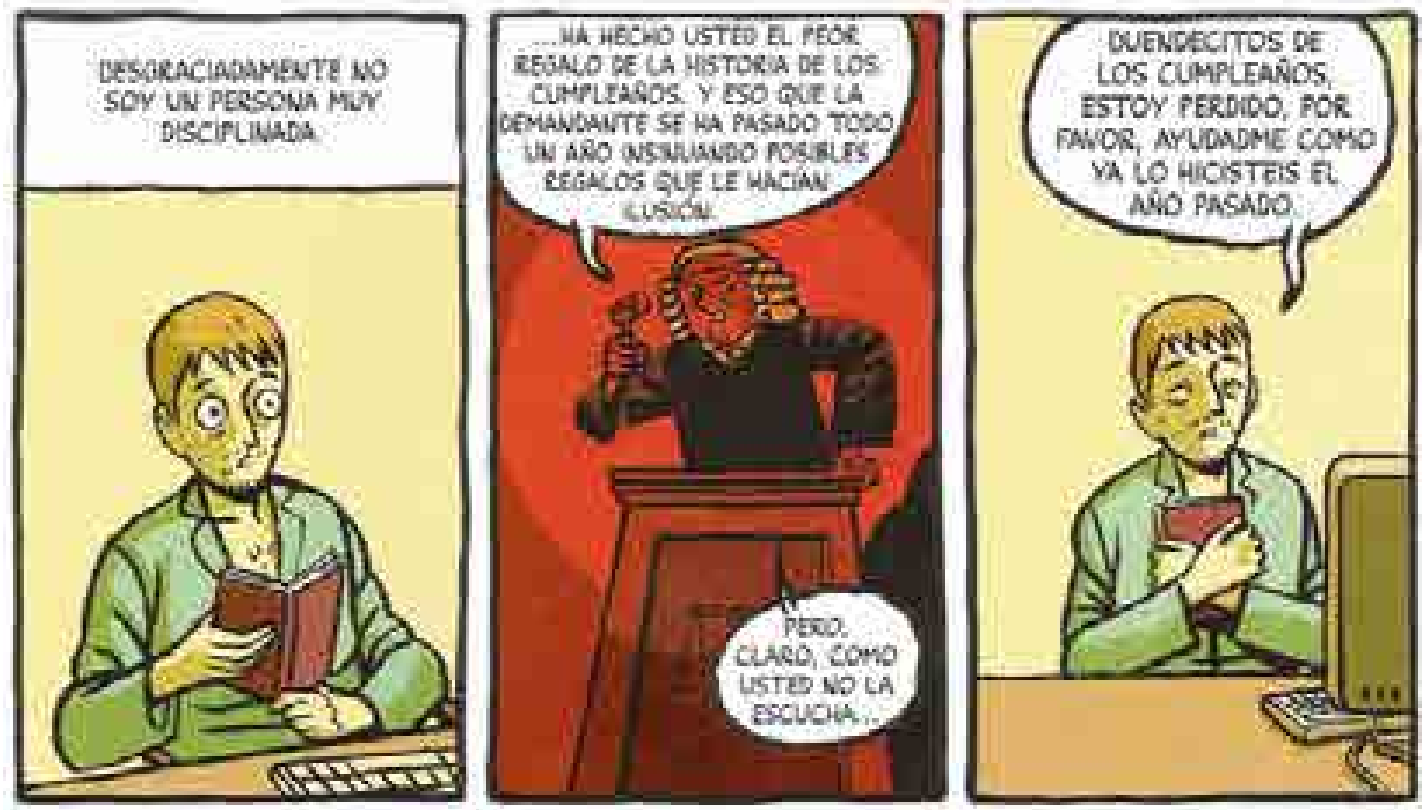

Fig. 14. Detalle de la página 51 de Memorias de un hombre en pijama, de Paco Roca
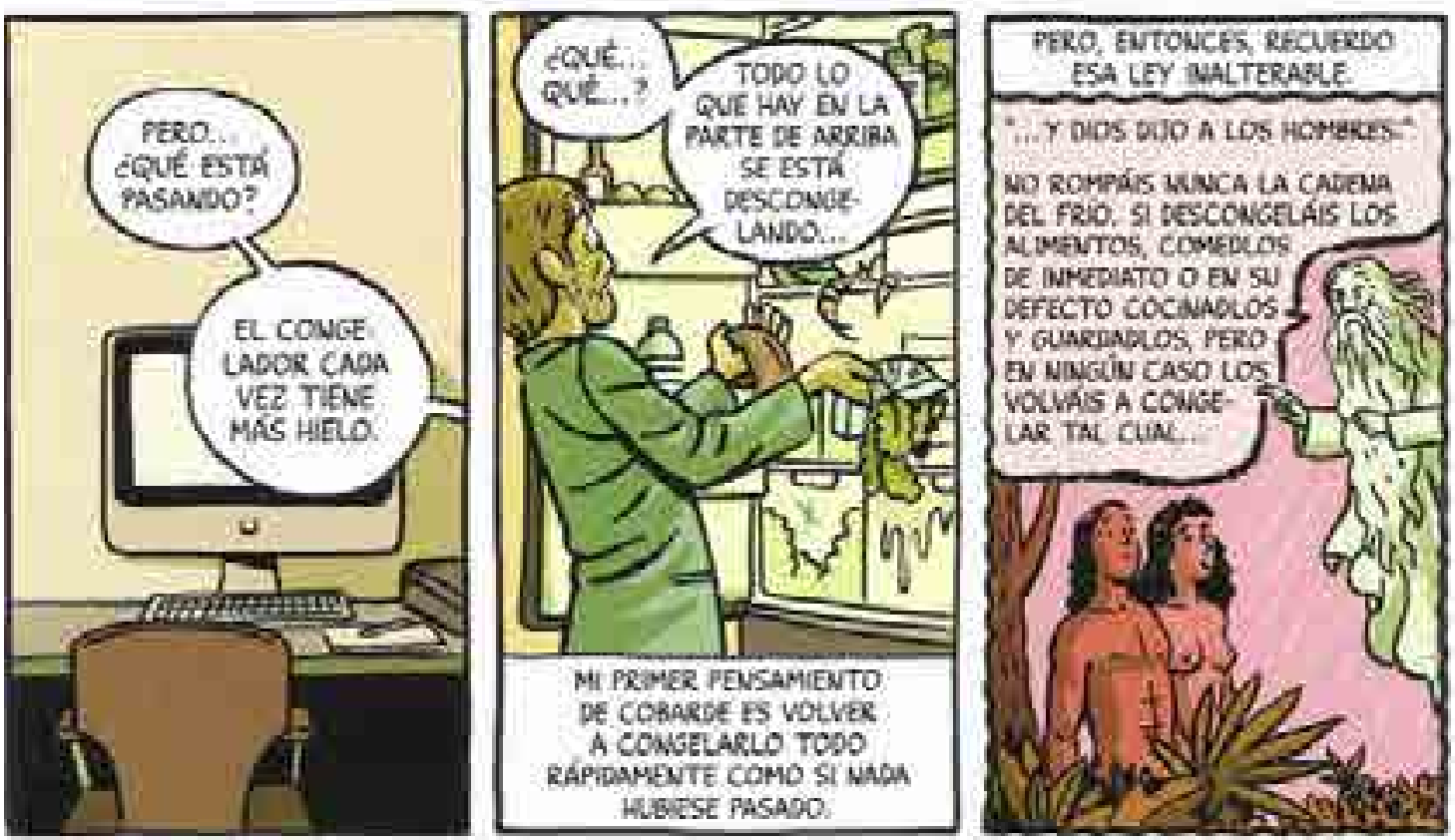

Fig. 15. Detalle de página 19 de Memorias de un hombre en pijama, de Paco Roca 
dando así fin a todo debate. La escena actual resulta sumamente cotidiana y constituye un buen barómetro de las prácticas sociales. Lo interesante es la operación del autor al situar este hecho en una cadena de acontecimientos históricos presididos por una lógica apuntada ya desde el inicio. Si tomamos los textos de la primera y la última viñeta observamos una evolución en la que la época actual puede verse como la desviación de una práctica que hablaba del ser humano y que ha sido descrita perfectamente desde otros registros (Turkle 2011). En definitiva parece como si la tecnología acabase por deshumanizar al hombre privándolo de uno de sus elementos constitutivos -el diálogo- para sustituirlo por otro -la información- en lo que parece ser una evolución pero que puede ser visto también, si lo examinamos de manera más atenta, como una pérdida. Los polos del relato enmarcados por los textos son muy explícitos en el devenir de los hechos: "Desde que el ser humano desarrollara el lenguaje, este siempre ha acompañado las comidas" refleja el inicio para acabar en "La tecnología $3 G$ ha convertido las comidas en solo comidas". Este mensaje llegaba tras dos viñetas en las que los comensales comían juntos pero sin hablar.

En otras ocasiones el efecto humorístico nace de una incongruencia inicial que, finalmente, es explicada ${ }^{12}$. Se puede advertir en las páginas en las que se ofrece la receta para realizar un "Sándwich de delicias de ibérico. Tiempo de preparación 15 horas y 10 minutos". La discrepancia entre el tiempo de preparación y el producto indicado llama la atención sobremanera. Cualquier lector presupone que un tiempo de preparación tan prolongado conlleva una elaboración sumamente compleja; el estupor nace de la comprobación de que el plato a preparar, al ser un sándwich, llevaría tan solo unos minutos. Descubrimos a lo largo del pequeño relato que, en realidad, el tiempo tan prolongado de realización tiene en cuenta el intento de preparación de un plato sofisticado que acaba en una catástrofe culinaria. Todo eso lleva quince horas, ya que se ha olvidado el horno encendido; los diez minutos restantes son los que se toma para preparar esos sándwichs, que quieren parecer una salida airosa pero ocultan bajo una fina capa humorística la torpeza del protagonista. El humo, que todavía pervive en las últimas viñetas mientras se comen el "suculento sándwich", es el recordatorio de un pequeño fracaso y de una salida optimista. Lo que resulta interesante de este pequeño relato es la polifonía discursiva que se oculta en las viñetas de Paco Roca. Los cartuchos de texto recuperan el discurso que remeda el estilo de las recetas y posee un tono impersonal. Este discurso del narrador va siendo ilustrado por las viñetas en las que se ve al alter ego gráfico de Paco Roca ejecu-

\footnotetext{
12 Para un análisis de la incongruencia y sus efectos humorísticos remito a Yus Ramos (199596). Rescato también las palabras de $\mathrm{M}^{\mathrm{a}}$ Ángeles Torres Sánchez en su estudio pragmático del humor verbal: "La incongruencia que subyace a todo hecho lúdico humorístico se podría interpretar igualmente como la razón del humor en una comunicación verbal. Desde el punto de vista pragmático, esta teoría nos parece sumamente interesante, y podríamos reinterpretarla del siguiente modo: el sentido del enunciado humorístico entra en contraste con el conjunto de supuestos contextuales accesibles, en su primer momento, al interlocutor. Esa inadecuación contextual obliga al oyente a inferir una intención lúdica en el hablante para poder haber emitido tal enunciado persiguiendo una óptica del mismo. La aparente incongruencia final, que ahora resulta interpretada adecuadamente, es la base de la hilaridad y el efecto lúdico en ambos interlocutores" (1999: 16).
} 
tar las instrucciones. Parece como si la narración gráfica estuviese supeditada a ese otro discurso que refiere las meticulosas instrucciones de la receta [Fig. 16].
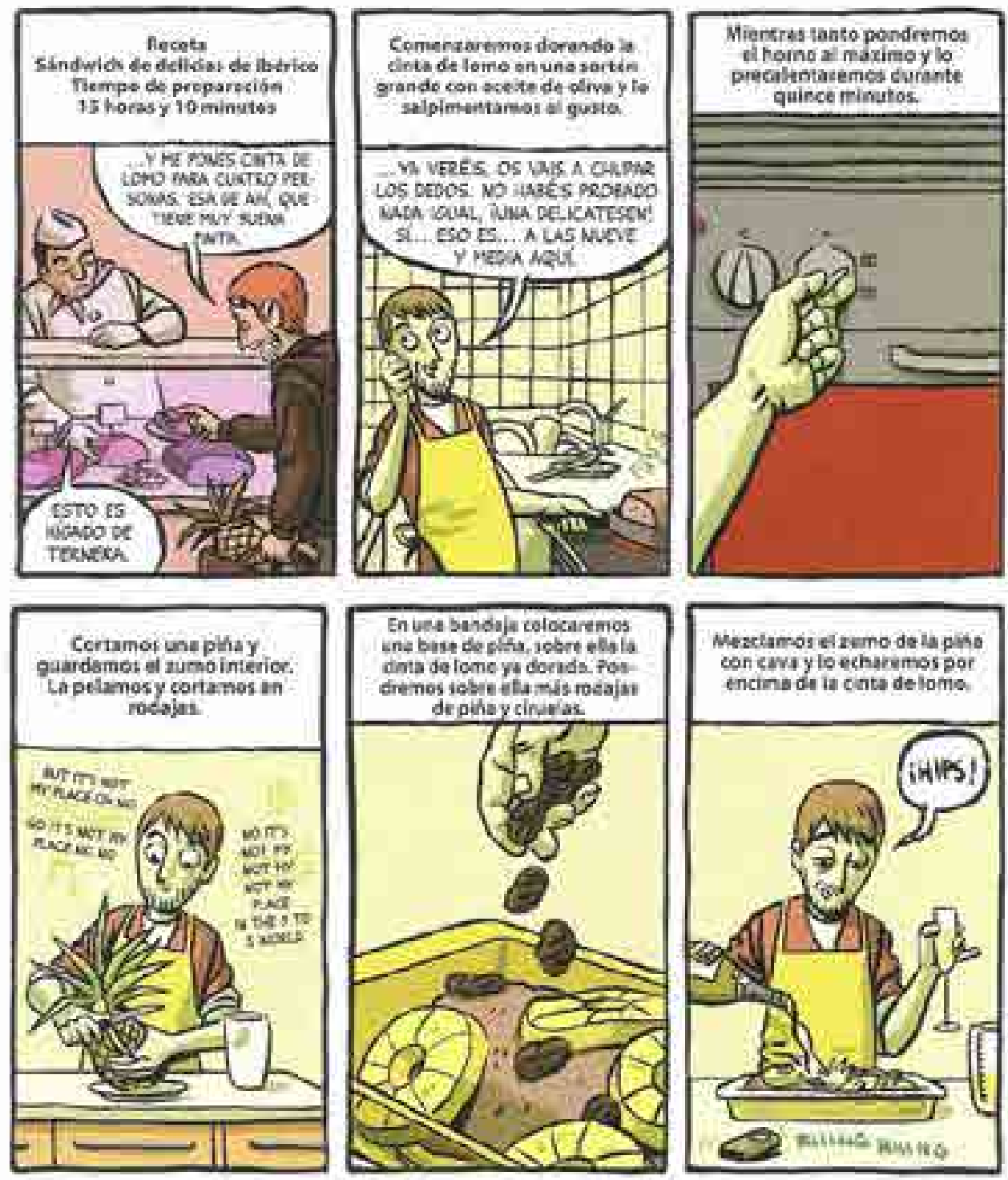

Fig. 16. Página 82 de Memorias de un hombre en pijama, de Paco Roca

Sin embargo, esto parece invertirse $y$, a partir de la viñeta en la que se constata el olvido involuntario del plato en el horno, los roles se intercambian. Ahora el 
discurso que parecía referir las instrucciones de la receta, y al cual se adecuaba la narración gráfica, varía su rumbo y se encarga de narrar no lo que debe hacerse sino el fracaso que ha tenido lugar [Fig. 17]. Lo novedoso reside en el hecho de que la voz sigue siendo igualmente impersonal pero ahora narra la situación absurda del fracaso. "Cuando el humo que sale del horno nos impida leer un
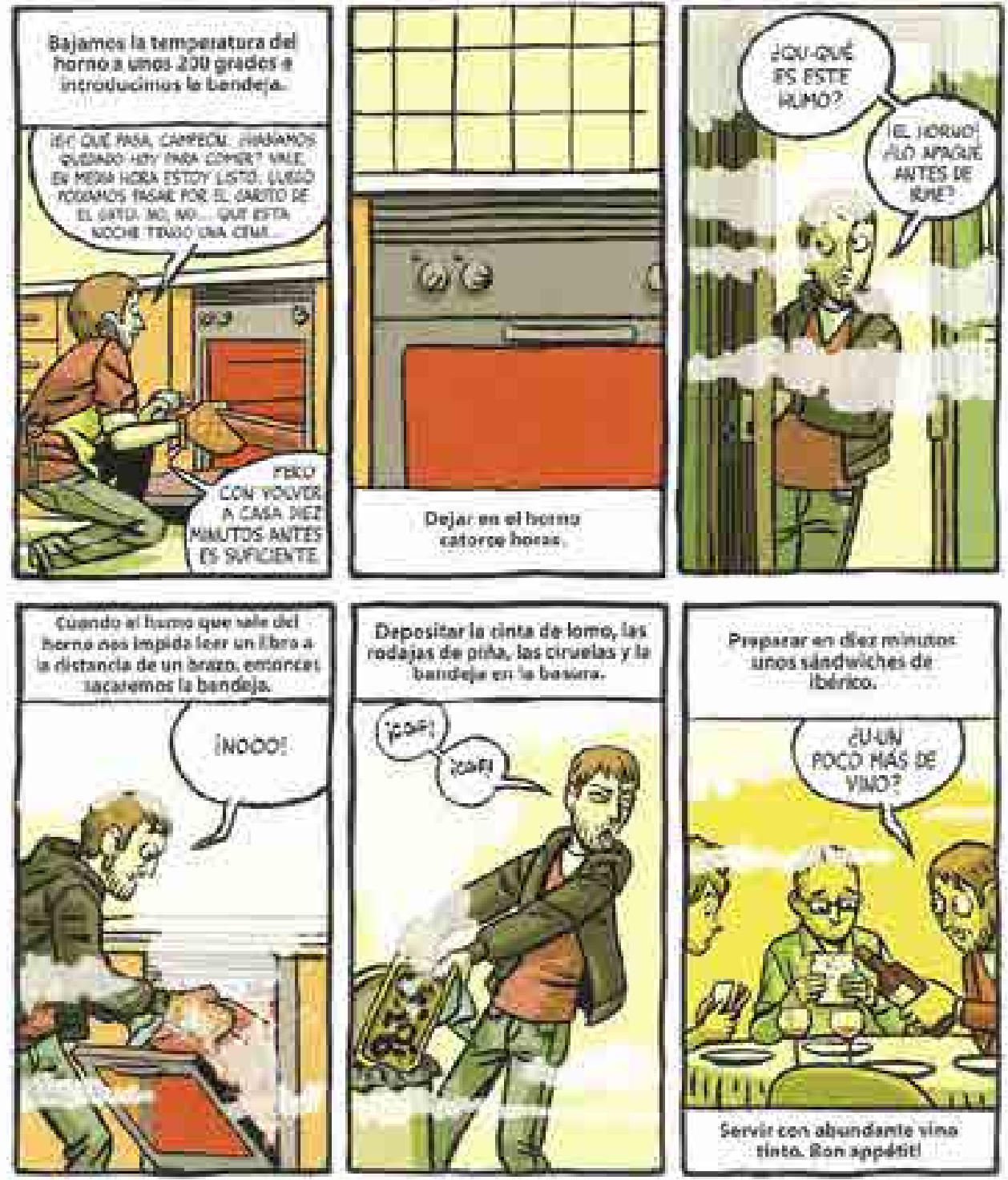

Fig. 17. Pág. 83 de Memorias de un hombre en pijama, de Paco Roca

318 Pasavento. Revista de Estudios Hispánicos, vol. III, n. ${ }^{2} 2$ (verano 2015), pp. 295-323, ISSN: 2255-4505 
libro a la distancia de un brazo, entonces sacaremos la bandeja. Depositar la cinta de lomo, las rodajas de piña, las ciruelas y la bandeja en la basura". Ese texto está trascribiendo fielmente lo que el personaje realiza; hasta ahora el lector entendía que el personaje hacía lo que el texto dictaba. Esa disonancia estilística viene dictada por la inserción de una nueva voz en el discurso de los cartuchos. La incorporación de esa nueva voz al relato no acabaría de entenderse sin la narración gráfica formalizada en las viñetas. Dicho de otro modo, lo que sucede en las viñetas acaba proyectándose en el discurso de los cartuchos; esa proyección inserta un elemento polifónico que crea una discordancia al tener que narrar a través del estilo recetario el fracaso de tal actividad. Parece haberse convertido en una realización paradójica: una receta que cuenta el fracaso de la preparación del plato. La última viñeta, en su sucinto mensaje, propone una solución rápida que no deja de ser incompatible con el propio proceso de la receta: "preparar en diez minutos unos sándwiches de ibérico". La receta ya no es un proceso sino que la voz ha visto usurpada su espacio discursivo por la ocurrencia del personaje que planea una salida alternativa que le permita cumplir con el compromiso con sus invitados. No será una cena suculenta; se servirá un sándwich, eso sí, de ibérico en lo que parece un vestigio de la delicatesen culinaria que había fracasado.

Por lo visto hasta ahora el humor parece haberse convertido en una gramática narrativa que permea gran parte de la obra de Paco Roca. Su originalidad no reside tanto en los procedimientos compositivos del chiste ya que éste no deja de ser un discurso perfectamente regulado con unos procedimientos formales tipificados: metáforas, hipérboles, juegos discursivos, información implícita, incongruencias, expectativas no cumplidas, etc. Lo realmente innovador está en el hecho de construir un personaje en el que deposita muchos de sus rasgos personales y lo convierte en un portavoz parcial de sí mismo (invididuo) que resulta un paradigma de una generación (perspectiva social) para examinar desde el ángulo del humor la sociedad coetánea. Ese afán inclusivo le permite situarse como un intermediario entre el propio discurso y la sociedad retratada atemperando de ese modo cualquier virulencia satírica. Por otra parte, ese carácter pseudo-autobiográfico emparentable con las prácticas de la autoficción, que tiene mucho de exageración, conecta con las corrientes modernas del cómic y del modelo de la novela gráfica. Al mismo tiempo, el hecho mismo de que se publicase primero en la prensa crea otro hilo de unión con la tradición del cómic, un lenguaje tan fuertemente conectado a los periódicos en su inicio. También el desarrollo de situaciones absurdas acaba estableciendo lazos con otras obras como Las calles de arena en las que el elenco de personajes que pueblan aquel barrio movedizo en su configuración urbanística viven atrapados por supersticiones y rituales repetitivos que, de algún modo, establecen un paralelismo con los usos y costumbres asumidos por una sociedad que parecen haber creado una telaraña que atrapa la razón para perpetuar lo ilógico. La liberación del protagonista de Las calles de arena llega tras el simbólico diluvio que acaba con un mundo viejo para inaugurar una nueva época junto a la mujer amada. El final viene presidido por una risa al descubrir el protagonista que la mujer que ama 
no era muda sino que había optado por el silencio como otro laberinto del que, finalmente, pudo huir.

Los personajes de Arrugas no podrán escapar a su destino: la enfermedad y la vejez pero, en su recorrido hacia el olvido, tejen una red de episodios festivos como la escapada de la residencia o las argucias que se inventan para poder engañar a los médicos en sus periódicos exámenes para comprobar cómo su memoria se va desmenuzando en fragmentos inconexos. Miguel, compañero del personaje protagonista -Emilio- , llega a afirmar que "La vejez es una broma pesada" (2008: 37). Dolores recuerda cómo Modesto logró engañarla mediante un ardid para que fuera su novia y Rosario mira por la ventana creyendo que viaja en el Orient Express. Son válvulas de escape para apartarse, siquiera un momento, de esa inercia desoladora que desarrolla en su médula este tipo de novelas gráficas ${ }^{13}$.

Si examinamos la importancia que dentro de la obra de Paco Roca tienen esas pequeñas historias de un hombre en pijama podemos otorgarle una función especial. De un lado recogían ese interés por lograr un relato generacional iniciado ya en Como cagallón por acequia pero, de otro, permitían que ese sustrato autobiográfico que permanecía latente emergiera a la luz ${ }^{14}$. En Arrugas se parte de situaciones reales documentadas pero todavía el autor no se incluye como personaje. Sin embargo, en Los surcos del azar existe un doble discurso no muy distante de lo que había hecho Spiegelman en su Maus. Por un lado se narra la historia de Miguel, que había participado en la liberación de París en la Segunda Guerra Mundial y, por otro, se integran las entrevistas de Paco Roca con el protagonista de su relato. De este modo el autor forma parte del universo narrado. No existen apenas esas dosis de humor, más visibles en otras obras, pero sí se observa una evolución en las relaciones entre Miguel y Paco Roca que pasan de una situación inicial de hostilidad en la que Miguel no quiere recordar su pasado a una especie de camaradería que permite a Paco Roca despertar el deseo de contar del protagonista de su obra. La relación se vuelve más distendida y existe cierta cordialidad que, a veces, vislumbra ciertas notas que pudieran rebajar ese carácter opresivo de los recuerdos deliberadamente silenciados. Podría uno preguntarse si ese ejercicio de Paco Roca de visitar la realidad vestido en pijama no es el fruto de una filosofía vitalista que mira al mundo con sorpresa

\footnotetext{
${ }^{13}$ Advierte Díaz de Guereñu: "si bien el humor salpica con cierta frecuencia las páginas de Arrugas, no suprime ni disimula el trasfondo trágico de la enfermedad y de la muerte" (2014: 160). Apunta sagazmente también en otro lugar: "En su conjunto, la atmósfera general del relato se caracteriza más bien por inclinarse a apreciar lo positivo" (2014: 161). También se destaca agudamente en estas páginas la imagen que trasmiten las distintas portadas y el episodio final que obliga al lector a una sonrisa final. Esa idea es algo premeditado si atendemos a las palabras del propio autor: "Encontrar el tono adecuado para contar la historia fue uno de los puntos complicados en Arrugas. Tenía que ser real y duro, pero optimista y con el humor justo para hacer digerible la historia, siendo siempre respetuoso con todas esas personas que había conocido" (Azpitarte 2009: 159).

14 Paco Roca reconoce esa veta autobiográfica de Como cagallón por acequia: "Amigos como Modesto, Ramón Palomar o yo mismo somos bastante reconocibles. Sin embargo, no se trata tanto de que los personajes sean ellos como de que los tomo de modelo para imaginar cómo actuarían ante ese tipo de situaciones" (Azpitarte 2009: 174).
} 
pero también con cierta comprensión. Lo cotidiano mirado con lupa puede ser absurdo pero contado desde cierta perspectiva alcanza la risa. Ese elemento cotidiano que bascula sobre lo traumático en Spiegelman o sobre lo melancólico en otros autores como Seth o Chris Ware es visto con humor, de la misma manera que ese humor estaba camuflado en otras obras de mayor extensión como son Arrugas o las Calles de arena. No era el humor en esas novelas gráficas la única vía de desactivar, al menos parcialmente, lo traumático pero colaboraba junto con la imaginación y la necesidad de la fantasía en hacer soportable el dolor y en buscar una vía para compartirlo.

En el caso de Paco Roca parece entreverse una evolución del relato con un toque autobiográfico a la página en la prensa en la que se introduce abiertamente como protagonista de sus propias historias. Sin embargo, no se trata de una transcripción notarial de lo que acontece en su vida sino que va implícita una transformación que se vale de la ficción y del humor. En este sentido podría hablarse de "autoficción cómica". Estos relatos, en su brevedad, se aferran a una gramática consolidada y longeva ya en la tradición del cómic y que se aparta, en cierto modo, de las prácticas de la novela gráfica. La exageración, y la consiguiente deformación que ello conlleva, actúan como mecanismo para inocular ciertas dosis de humor e interés en lo anodino de cualquier vida. No es Paco Roca un caso aislado, otros autores como Lewis Trondheim o Guillaume Bouzard son un buen ejemplo para ver cómo esta "autoficción cómica" revitaliza nuevas formas de contar a la luz de viejos procedimientos. La risa es una invitación a visitar los espacios domésticos de la mano del artista que oficia como maestro de ceremonias en el espectáculo del día a día.

\section{OBRAS CITADAS}

Azpitarte, Koldo (2009): Senderos. Una retrospectiva de la obra de Paco Roca. Bilbao, Laukatu.

Baetens, Jan (2011): "Dominique Goblet: The List Principle and the Meaning of Form". En: Michael A. Chaney (ed.): Graphic Subjects. Madison (Wisconsin), University of Wisconsin Press, pp. 76-92.

Baetens, Jan, y Frey, Hugo (2015): The Graphic Novel. An Introduction. Nueva York, Cambridge University Press.

Beaty, Bart (2007): Unpopular Culture. Transforming the European Comic Book in the 1990s. Toronto, University of Toronto Press.

— (2013): "La autenticidad de la autobiografía". En: José Manuel Trabado Cabado (ed.): La novela gráfica. Poéticas y modelos narrativos. Madrid, Arco Libros, pp. 243-286.

Bouzard, Guillaume (2013): Moi, Bd. París, Fluide Glacial.

Calle, Ángel de la (2006): Diarios de festival. Gijón, AAHA.

- (2007): Modotti. Una mujer del siglo XXI. Madrid, Ediciones Sins Entido.

Casas, Ana (ed.) (2012): La autoficción. Reflexiones teóricas. Madrid, Arco Libros.

Cates, Isaac (2011): "The Diary Comic". En: Michael A. Chaney (ed.): Graphic Subjects. Madison, (Wisconsin), University of Wisconsin Press, pp. 209-226. 
Chaney, Michael A. (ed.) (2011): Graphic Subjects. Madison (Wisconsin), University of Wisconsin Press.

Chute, Hillary (2006): "The Shadow of a Past Time: History and Graphic Representation in Maus", Twentieth-Century Literature, vol. 52 n. ${ }^{\circ}$ 2, pp. 199-230.

- (2010): Graphic Women. Life Narrative \& Contemporary Comics. Nueva York, Columbia University Press.

— (2011): "Materializing Memory: Lynda Barry's One Hundred Demons". En: Michael A. Chaney (ed.): Graphic Subjects. Madison (Wisconsin), University of Wisconsin Press, pp. 282-309.

Davodeau, Étienne (2014): Los ignorantes. Barcelona, La Cúpula.

Díaz de Guereñu, Juan Manuel (2014): Hacia un cómic de autor. A propósito de Arrugas y otras novelas gráficas. Bilbao, Universidad de Deusto.

Dejasse, Erwin; Habrand, Tanguy; y Meesters, Gert (eds.) (2011): L'Association. Une utopie éditoriale et esthétique. Bruselas, Les Impressions Nouvelles.

El Refaie, Elisabeth (2012): Autobiographical Comics. Life Writing in Pictures. Jackson, University Press of Mississippi.

García, Santiago (2010): La novela gráfica. Bilbao, Astiberri.

Gasca, Luis, y Gubern, Román (1994): El discurso del cómic. Madrid, Cátedra.

Gilmore, Leigh (2011): "Witnessing Persepolis. Comics, Trauma and Childhood Testimony". En: Michael A. Chaney (ed.): Graphic Subjects. Madison (Wisconsin), University of Wisconsin Press, pp. 157-163.

Gravett, Paul (2005): Graphic Novels. Everything you Need to Know. Nueva York, Collins Design.

Larcenet, Manu (2012): Los combates cotidianos. Barcelona, Norma Editorial.

Lefrève, Pascal (2013): "La importancia de ser publicado". En: José Manuel Trabado Cabado (ed.): La novela gráfica. Poéticas y modelos narrativos. Madrid, Arco Libros, pp. 83102.

Peyraud, Jean-Philippe (1999): Mine de rien. Tours, La comédie illustrée.

Roca, Paco (2008): Arrugas. Bilbao, Astiberri.

- (2011): Memorias de un hombre en pijama. Bilbao, Astiberri.

- (2014): Andanzas de un hombre en pijama. Bilbao, Astiberri.

Schneider, Greice (2010): "Comics as Everyday Life: from Ennui to Contemplation", European Comic Art, vol. 1, n 1, pp. 37-63.

Simon, Justine (2008): "Le Combat Ordinaire de Marco... euh.... Manu Larcenet: Une BD réalité à dimension autofictionnelle" Image [\&] Narrative: <http://www.imageandnarrative. be/autofiction2/simon.htm> [última visita 29.01.2015].

Spiegelman, Art (2011): Metamaus, Nueva York, Pantheon Books.

Tolmie, Jane (ed.) (2013): Drawing from Life. Memory and Subjectivity in Comic Art. Jackson, University Press of Mississippi.

Trabado Cabado, José Manuel (2012): "Construcción narrativa e identidad gráfica en el cómic autobiográfico", Rilce, vol. 28, n. ${ }^{\circ}$ 1, pp. 222-255.

— (2013): "La novela gráfica en el laberinto de los formatos del cómic". En: José Manuel Trabado Cabado (ed.): La novela gráfica. Poéticas y modelos narrativos. Madrid, Arco Libros, pp. 11-61. 
— (2013): "Extravíos en el laberinto. Poética de lo fantástico en la novela gráfica de Paco Roca", Brumal. Revista de Investigación sobre lo fantástico, vol. I, n. 2, pp. 349-371. (2014): "Bocetos de lo cotidiano: Fórmulas del diario en el cómic". En: Domingo Sánchez-Mesa, José Manuel Ruiz Martínez y Azucena González Blanco (eds.): Teoría y comparatismos: tradición y nuevos espacios. Actas del I Congreso Internacional de ASETEL. Granada, Universidad de Granada, pp. 1461-1478.

Torres Sánchez, Ma Ángeles (1999): Estudio pragmático del humor verbal. Cádiz, Universidad de Cádiz.

Trondheim, Lewis (2005): Mis circunstancias. Bilbao, Astiberri.

Turkle, Sherry (2011): Alone Together. Why We Expect More from Technology and Less From Each Other. Nueva York, Basic Books.

Vigara Tause, Ana María (1994): El chiste y la comunicación lúdica: lenguaje y praxis. Madrid, Ediciones Libertarias.

Wolk, Douglas (2007): Reading Comics and What They Mean. How Graphic Novels Work. Filadelfia, Da Capo Press.

Yus Ramos, Francisco (1995-96): "La Teoría de la Relevancia y la estrategia humorística de la incongruencia-resolución", Pragmalingüística, vol. 3-4, pp. 497-508.

- (1996): Conversational Cooperation in Alternative Comics. Alicante, Universidad de Alicante. 